\title{
A Schiff-Base Bibracchial Lariat Ether Forming a Cryptand-like Cavity for Lanthanide lons
}

\author{
Marina González-Lorenzo, ${ }^{\dagger}$ Carlos Platas-Iglesias, ${ }^{\dagger}$ Fernando Avecilla, ${ }^{\dagger}$ Carlos F. G. C. Geraldes, ${ }^{\ddagger}$ \\ Daniel Imbert,, Jean-Claude G. Bünzli,, Andrés de Blas,,${ }^{, \dagger}$ and Teresa Rodríguez-Blas ${ }^{*, \dagger}$ \\ Departamento de Química Fundamental, Facultade de Ciencias, Universidade da Coruña, \\ Campus de A Zapateira s/n, 15071, A Coruña, Spain, Institute of Molecular and \\ Biological Chemistry, Swiss Federal Institute of Technology Lausanne, BCH 1402, \\ CH-1015 Lausanne, Switzerland, and Departamento de Bioquímica, Faculdade de Ciências e \\ Tecnologia, e Centro de Neurociências, Universidade de Coimbra, Apartado 3126, \\ P-3049 Coimbra, Portugal \\ Received January 13, 2003
}

\begin{abstract}
We report here a structural and photophysical study of lanthanide(III) complexes with the di-deprotonated form of the bibracchial lariat ether $N, N^{\prime}$-bis(2-salicylaldiminobenzyl)-1,10-diaza-15-crown-5. The X-ray crystal structures of $\left[\mathrm{Ce}\left(\mathrm{L}^{2}-2 \mathrm{H}\right)\right]\left(\mathrm{ClO}_{4}\right) \cdot 0.5 \mathrm{H}_{2} \mathrm{O}(2)$ and $\left[\mathrm{Sm}\left(\mathrm{L}^{2}-2 \mathrm{H}\right)\right]\left(\mathrm{ClO}_{4}\right) \cdot \mathrm{C}_{3} \mathrm{H}_{8} \mathrm{O}(5 \mathrm{~b})$ show the metal ion being nine-coordinated and deeply buried in the cavity of the dianionic receptor. Thanks to the formation of a pseudomacrocycle through $\pi-\pi$ interaction between one of the phenol rings and one of the benzyl rings, the complexes present a cryptand-like structure in the solid state. ${ }^{1} \mathrm{H}$ and ${ }^{13} \mathrm{C}$ NMR studies on the $\mathrm{La}(\mathrm{III})$ complex point that the solid state structure is essentially maintained in acetonitrile solution. High-resolution laser-excited emission spectra of the crystalline $\mathrm{Eu}(\mathrm{III})$ complex demonstrate the presence of several coordination sites arising from different conformations of the crown moiety. The ligand-to-Eu(III) energy transfer is relatively efficient at low temperature, but back transfer is implied in the deactivation process, especially at room temperature, because the ligand triplet state lies at very low energy. However, the low energy of the ${ }^{3} \pi \pi^{*}$ state provides an efficient conversion of the visible light absorbed into nearinfrared light emitted by the $\mathrm{Nd}(\mathrm{III})$ ion.
\end{abstract}

\section{Introduction}

Lanthanide coordination compounds ${ }^{1}$ are the subject of intense research efforts due to their applications as contrast agents for NMR imaging, ${ }^{2}$ as catalysts in RNA hydrolysis, ${ }^{3}$ or as active agents in cancer radiotherapy. ${ }^{4}$ It has also been shown that the Eu(III) ion behaves as an extremely sensitive

* To whom correspondence should be addressed. E-mail: mayter@udc.es.

†niversidade da Coruña.

$\div$ Universidade de Coimbra.

$\S$ Swiss Federal Institute of Technology Lausanne.

(1) Bünzli, J.-C. G. In Rare Earths; Saez-Puche, R., Caro, P., Eds.; Editorial Complutense: Madrid, 1998; p $223 \mathrm{ff}$.

(2) Lauffer, R. B. In MRI Clinical Magnetic Resonance Imaging, 2nd ed.; Edelman, R. R., Zlatkin, M. B., Hesselink, J. R., Eds.; W. B. Saunders Co.: Philadelphia, PA, 1996; Vol. 1, Chapter 5. Caravan, P.; Ellinson, J. J.; McMurry, T. J.; Lauffer, R. B. Chem. Rev. 1999, 99, 2293.

(3) Bruice, T. C.; Tsubouchi, A.; Dempcy, R. O.; Olson, L. P. J. Am. Chem. Soc. 1996, 118, 9867. Hurst, P.; Takasaki, B. K.; Chin, J. J. Am. Chem. Soc. 1996, 118, 9982.

(4) De Nardo, G. L.; Mirik, G. R.; Kroger, L. A.; O’Donnel, R. T.; Meares, C. F.; De Nardo, S. L. J. Nucl. Med. 1996, 37, 451. Heeg, M. J.; Jurisson, S. S. Acc. Chem. Res. 1999, 32, 1053.

6946 Inorganic Chemistry, Vol. 42, №. 21, 2003 probe responding to faint chemical differences, revealing slightly unequivalent moieties in molecular solids. ${ }^{5}$ Such a detailed analysis is not amenable to X-ray- or neutrondiffraction studies, which yield an averaged image of the unit-cell content, whereas the faster time scale of luminescence experiments provides an instantaneous representation of it. Moreover, lanthanide-containing luminescent stains ${ }^{5}$ are valuable for the development of fluoroimmunoassays ${ }^{6}$ and of complexes which signal changes in $\mathrm{pH}, \mathrm{pO}_{2}$, or chloride concentration. ${ }^{7}$ A unique combination of features must be realized to design a lanthanide luminescence sensor: (i) presence of multiple absorbing groups suitable for energy transfer (antenna $\operatorname{effect}^{8}$ ); (ii) high thermodynamic

(5) Bünzli, J.-C. G. In Lanthanide Probes in Life, Chemical and Earth Science; Bünzli, J.-C. G., Choppin, G. R., Eds.; Elsevier Science Publ. BV: Amsterdam, 1989; Chapter 7.

(6) Mathis, G. In Rare Earths; Saez-Puche, R., Caro, P., Eds.; Editorial Complutense: Madrid, 1998.

(7) Aime, S.; Barge, A.; Botta, M.; Howard, J. A. K.; Kataky, R.; Lowe, M. P.; Maloney, J. M.; Parker, D.; De Sousa, A. S. Chem. Commun. 1999, 1047.

10.1021/ic034024t CCC: $\$ 25.00 \quad$ C 2003 American Chemical Society Published on Web 09/23/2003 
and kinetic inertness; (iii) protection of the metal ion from various quenching or back transfer processes. ${ }^{9}$ Several classes of receptors have been designed to meet these requirements, such as preorganized ${ }^{10}$ and predisposed ${ }^{11}$ macrocyclic ligands, multidentate podands, ${ }^{12}$ or self-assembled lanthanide triplestranded helicates. ${ }^{13}$ In addition, Schiff-base macrocyclic receptors have also turned out to be good candidates for the sensitization of $\mathrm{Eu}$ (III) because the electronic delocalization in the ligand induces a relatively low-lying triplet state, which also provides an efficient conversion of the visible light absorbed into near-infrared light emitted by $\mathrm{Nd}(\mathrm{III})$ or $\mathrm{Yb}(\mathrm{III})$ ions. ${ }^{14,15}$

The cyclic framework of crown ethers affords an interesting platform for the complexation of metal ions. Moreover, the relative facility with which crown ethers can be functionalized with pendant arm(s) containing additional donor atom(s) allows one to enhance the cation binding ability and the selectivity of the parent crown ether. ${ }^{16}$ In particular, the hard acid character of the crown moiety makes crown ethers interesting potential ligands for the complexation of trivalent lanthanide ions ${ }^{17}$ or for the design of efficient lanthanidebased luminescent devices. In a recent work, ${ }^{18}$ we described the coordinative ability of the di-deprotonated lariat ether $N, N^{\prime}$-bis(2-salicylaldiminobenzyl)-4,13-diaza-18-crown-6 ( $\mathbf{L}^{\mathbf{1}}$; Chart 1) toward lanthanide(III) ions. This receptor forms stable complexes in acetonitrile solution only with the three lightest lanthanide ions ( $\mathrm{La}, \mathrm{Ce}$, and $\mathrm{Pr}$ ), as a consequence of the combination of the relatively large ring size of the crown moiety and the presence of relatively rigid pendant arms.

Herein, we present the synthesis and the structural characterization of lanthanide complexes with formula [Ln$\left.\left(\mathbf{L}^{2}-2 \mathrm{H}\right)\right]\left(\mathrm{ClO}_{4}\right) \cdot x \mathrm{H}_{2} \mathrm{O} \cdot y \mathrm{C}_{3} \mathrm{H}_{8} \mathrm{O}(\mathrm{Ln}=\mathrm{La}-\mathrm{Ho})$, where $\mathbf{L}^{2}$ is the lariat ether $N, N^{\prime}$-bis(2-salicylaldiminobenzyl)-1,10-diaza15-crown-5. The crystal structures of the Ce(III) and Sm(III) complexes were determined by X-ray crystallography. ${ }^{1} \mathrm{H}$

(8) Sabbatini, N.; Perathoner, S.; Balzani, V.; Alpha, B.; Lehn, J.-M. In Supramolecular Chemistry; Balzani, V., Ed.; Reidel Publishing Co.: Dordrecht, The Netherlands, 1987.

(9) Blasse, G. Phys. Status Solidi A 1992, 130, K85. Bünzli, J.-C. G.; Froidevaux, P.; Harrowfield, J. M. Inorg. Chem. 1993, 32, 3306.

(10) Alexander, V. Chem. Rev. 1995, 95, 273.

(11) Bünzli, J.-C. G.; André, N.; Elhabiri, M.; Muller, G.; Piguet, C. J. Alloys Compd. 2000, 303/304, 66.

(12) Jones, P. L.; Amoroso, A. J.; Jeffery, J. C.; McCleverty, J. A.; Psillakis, E.; Rees, L. H.; Ward, M. D. Inorg. Chem. 1997, 36, 10. Renaud, F.; Piguet, C.; Bernardinelli, G.; Hopfgartner, G.; Bünzli, J.-C. G. Chem. Commun. 1999, 457. Fatin-Rouge, N.; Tóth, E.; Perret, D.; Backer, R. H.; Merbach, A. E.; Bünzli, J.-C. G. J. Am. Chem. Soc. 2000, 122, 10810 .

(13) Piguet C.; Bünzli, J.-C. G. Chem. Soc. Rev. 1999, 28, 347.

(14) Platas, C.; Avecilla, F.; de Blas, A.; Rodríguez-Blas, T.; Geraldes, C. F. G. C.; Tóth, É.; Merbach, A. E.; Bünzli, J.-C. G. J. Chem. Soc., Dalton Trans. 2000, 611.

(15) Rodríguez-Cortiñas, R.; Avecilla, F.; Platas-Iglesias, C.; Imbert, D.; Bünzli, J.-C. G.; de Blas, A.; Rodríguez-Blas, T. Inorg. Chem. 2002, 41,5336 .

(16) Gokel, G. W.; Korzeniowski, S. H. In Macrocyclic Polyether Synthesis; Springer: Berlin, 1982; pp 6, 39. Nakatsuji, Y.; Nakamura, T.; Yometani, M.; Yuya H.; Okahara, M. J. Am. Chem. Soc. 1988, 110 531.

(17) Liu, Y.; Han, B.-H.; Li, Y.-M.; Chen, R.-T.; Ouchi, M.; Inoue, Y. J. Chem. Phys. 1996, 100, 17361.

(18) Platas, C.; Avecilla, F.; de Blas, A.; Rodríguez-Blas, T.; Bastida, R.; Macías, A.; Rodríguez, A.; Adams, H. J. Chem. Soc., Dalton Trans. 2001, 1699.
Chart 1

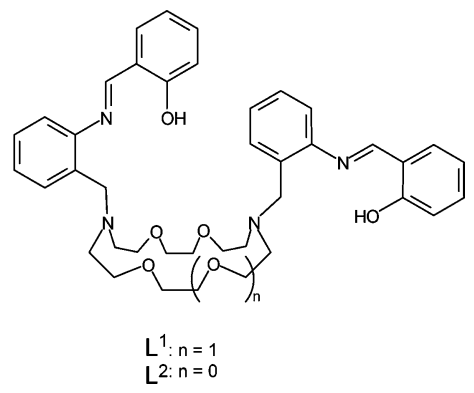

and ${ }^{13} \mathrm{C}$ NMR spectroscopy has been used to obtain structural information on the Ln(III) complexes in acetonitrile solution. Finally, the photophysical properties of the Nd(III), Eu(III), and $\mathrm{Gd}(\mathrm{III})$ complexes are reported and a high-resolution luminescence study is presented on the $\mathrm{Eu}$ (III) complex to obtain structural information both in the solid state and in solution.

\section{Experimental Section}

Materials. $N, N^{\prime}$-Bis(2-aminobenzyl)-1,10-diaza-15-crown-5 was prepared by reduction of the corresponding dinitro precursor as previously described. ${ }^{19}$ Lanthanide(III) perchlorates hydrates were purchased from Alfa laboratories and used as received. Salicylaldehyde (98\%) and triethylamine (99\%) were commercial reagents from Aldrich. Acetonitrile- $d_{3}$ for NMR measurements (Merck, 99\% D) was used as received.

Caution! Perchlorate salts combined with organic ligands are potentially explosive and should be handled in small quantity and with the necessary precautions. ${ }^{20}$

Preparation of the Complexes. $N, N^{\prime}$-Bis(2-aminobenzyl)-1,10diaza-15-crown-5 $(0.050 \mathrm{~g}, 0.108 \mathrm{mmol})$ and $0.026 \mathrm{~g}$ of salicylaldehyde $(0.216 \mathrm{mmol})$ were dissolved in 2-propanol $(30 \mathrm{~mL})$ and heated to reflux. After $1 \mathrm{~h}$ a solution of $0.022 \mathrm{~g}$ of triethylamine $(0.216 \mathrm{mmol})$ in $10 \mathrm{~mL}$ of 2-propanol was added, and the reflux was maintained for $30 \mathrm{~min}$. A solution of the corresponding hydrated lanthanide(III) perchlorate $(0.108 \mathrm{mmol})$ in $25 \mathrm{~mL}$ of the same solvent was then added, the resultant solution was refluxed for $2 \mathrm{~h}$ and filtered while hot, and the filtrate was left to evaporate slowly at room temperature to yield yellow crystals that were collected by filtration and dried under vacuum over $\mathrm{CaCl}_{2}$.

$\left[\mathbf{L a}\left(\mathbf{L}^{2}-\mathbf{2 H}\right)\right]\left(\mathbf{C l O}_{4}\right) \cdot 2 \mathbf{H}_{2} \mathbf{O}$ (1). Yield: $0.056 \mathrm{~g}, 57 \%$. Anal. Found: C, 50.4; $\mathrm{H}, 4.7 ; \mathrm{N}, 6.4$. Calcd for $\mathrm{C}_{38} \mathrm{H}_{42} \mathrm{ClLaN}_{4} \mathrm{O}_{9}$. $1.5 \mathrm{H}_{2} \mathrm{O}: \mathrm{C}, 50.7 ; \mathrm{H}, 5.0 ; \mathrm{N}, 6.2 . v_{\max } / \mathrm{cm}^{-1}: 1607(\mathrm{C}=\mathrm{N}), 1535$ $(\mathrm{C}=\mathrm{C}), 1088$ and $623\left(\mathrm{ClO}_{4}^{-}\right)$. MS (FAB+) $[\mathrm{m} / \mathrm{z}(\% \mathrm{BPI})]: 773$ $(100 \%)\left[\mathrm{La}\left(\mathbf{L}^{2}-2 \mathrm{H}\right)\right]^{+}$. Solution ${ }^{1} \mathrm{H}$ and ${ }^{13} \mathrm{C}$ NMR: Table 4.

[Ce( $\left.\left(\mathbf{L}^{2}-\mathbf{2 H}\right)\right]\left(\mathbf{C l O}_{4}\right) \cdot \mathbf{0 . 5} \mathbf{H}_{2} \mathbf{O}$ (2). Yield: $0.078 \mathrm{~g}, 76 \%$. Anal. Found: C, 51.7; H, 4.8; N, 6.3. Calcd for $\mathrm{C}_{38} \mathrm{H}_{42} \mathrm{CeClN}_{4} \mathrm{O}_{9}$. $0.5 \mathrm{H}_{2} \mathrm{O}: \mathrm{C}, 51.7 ; \mathrm{H}, 4.9 ; \mathrm{N}, 6.3 . v_{\max } / \mathrm{cm}^{-1}: 1607(\mathrm{C}=\mathrm{N}), 1535$ $(\mathrm{C}=\mathrm{C}), 1113$ and $623\left(\mathrm{ClO}_{4}^{-}\right)$. MS $(\mathrm{FAB}+)[\mathrm{m} / z(\% \mathrm{BPI})]: 774$ $(100 \%)\left[\mathrm{Ce}\left(\mathbf{L}^{2}-2 \mathbf{H}\right)\right]^{+}$. Yellow single crystals of $\mathbf{2}$, suitable for single-crystal X-ray diffraction analysis, were grown by slow evaporation of 2-propanol solutions of the complex.

[Pr( $\left.\left.\mathbf{L}^{2}-\mathbf{2 H}\right)\right]\left(\mathbf{C l O}_{4}\right)(3)$. Yield: $0.088 \mathrm{~g}, 86 \%$. Anal. Found: C, 52.1; H, 4.8; N, 6.4. Calcd for $\mathrm{C}_{38} \mathrm{H}_{42} \mathrm{ClN}_{4} \mathrm{PrO}_{9}$ : C, 52.2; H, 4.8; $\mathrm{N}$, 6.4. $v_{\max } / \mathrm{cm}^{-1}: 1609(\mathrm{C}=\mathrm{N}), 1537(\mathrm{C}=\mathrm{C}), 1119$ and 631

(19) Esteban, D.; Bañobre, D.; de Blas, A.; Rodríguez-Blas, T.; Bastida, R.; Macías, A.; Rodríguez, A.; Fenton, D. E.; Adams, H.; Mahía, J. Eur. J. Inorg. Chem. 2000, 1445.

(20) Wolsey, W. C. J. Chem. Educ. 1973, 50, A335. 
González-Lorenzo et al.

$\left(\mathrm{ClO}_{4}^{-}\right)$. MS (FAB+) $[\mathrm{m} / \mathrm{z}(\% \mathrm{BPI})]: 775(100 \%)\left[\operatorname{Pr}\left(\mathbf{L}^{2}-2 \mathrm{H}\right)\right]^{+}$ $\Lambda_{\mathrm{M}}$ (acetonitrile): $132 \mathrm{~cm}^{2} \Omega^{-1} \mathrm{~mol}^{-1}$ (1:1 electrolyte).

[Nd(L $\left.\left.\mathbf{L}^{2}-\mathbf{H}\right)\right]\left(\mathbf{C l O}_{4}\right) \cdot \mathbf{H}_{2} \mathbf{O}$ (4). Yield: $0.046 \mathrm{~g}, 44 \%$. Anal. Found: C, 50.9; H, 5.1; N, 5.7. Calcd for $\mathrm{C}_{38} \mathrm{H}_{42} \mathrm{ClN}_{4} \mathrm{NdO}_{9}$. 0.5 $\mathrm{C}_{3} \mathrm{H}_{7} \mathrm{O}: \mathrm{C}, 50.9 ; \mathrm{H}, 5.0 ; \mathrm{N}, 6.3 . v_{\max } / \mathrm{cm}^{-1}: 1609(\mathrm{C}=\mathrm{N}), 1538$ $(\mathrm{C}=\mathrm{C}), 1116$ and $622\left(\mathrm{ClO}_{4}^{-}\right)$. MS $(\mathrm{FAB}+)[\mathrm{m} / \mathrm{z}(\% \mathrm{BPI})]: 778$ $(100 \%)\left[\mathrm{Nd}\left(\mathbf{L}^{2}-2 \mathrm{H}\right)\right]^{+} . \Lambda_{\mathrm{M}}$ (acetonitrile): $161 \mathrm{~cm}^{2} \Omega^{-1} \mathrm{~mol}^{-1}(1: 1$ electrolyte).

[Sm( $\left.\left.\mathbf{L}^{2}-\mathbf{2 H}\right)\right]\left(\mathbf{C l O}_{4}\right) \cdot \mathbf{H}_{2} \mathbf{O}$ (5). Yield: $0.074 \mathrm{~g}, 70 \%$. Anal. Found: C, 50.4; H, 4.6; N, 6.1. Calcd for $\mathrm{C}_{38} \mathrm{H}_{42} \mathrm{ClN}_{4} \mathrm{O}_{9} \mathrm{Sm} \cdot \mathrm{H}_{2} \mathrm{O}$ : C, 50.6; H, 4.9; N, 6.2. $v_{\max } / \mathrm{cm}^{-1}: 1608(\mathrm{C}=\mathrm{N}), 1536(\mathrm{C}=\mathrm{C})$, 1117 and $624\left(\mathrm{ClO}_{4}^{-}\right)$. MS (FAB+) [m/z (\% BPI)]: $786(100 \%)$ $\left[\mathrm{Sm}\left(\mathbf{L}^{2}-2 \mathrm{H}\right)\right]^{+} . \Lambda_{\mathrm{M}}$ (acetonitrile): $134 \mathrm{~cm}^{2} \Omega^{-1} \mathrm{~mol}^{-1}$ (1:1 electrolyte). Yellow single crystals with formula $\left[\mathrm{Sm}\left(\mathbf{L}^{2}-2 \mathrm{H}\right)\right]\left(\mathrm{ClO}_{4}\right)$. $\mathrm{C}_{3} \mathrm{H}_{8} \mathrm{O}(\mathbf{5 b})$, suitable for single-crystal $\mathrm{X}$-ray diffraction analysis, were grown by slow evaporation of 2-propanol solutions of the complex. Solution ${ }^{1} \mathrm{H}$ and ${ }^{13} \mathrm{C}$ NMR: Table 4.

$\left[\mathbf{E u}\left(\mathrm{L}^{2}-\mathbf{2 H}\right)\right]\left(\mathrm{ClO}_{4}\right) \cdot \mathbf{C}_{3} \mathbf{H}_{7} \mathbf{O}$ (6). Yield: $0.026 \mathrm{~g}, 24 \%$. Anal. Found: C, 52.2; H, 5.3; N, 5.9. Calcd for $\mathrm{C}_{38} \mathrm{H}_{42} \mathrm{ClEuN}_{4} \mathrm{O}_{9}$. $\mathrm{C}_{3} \mathrm{H}_{7} \mathrm{O}: \mathrm{C}, 52.0 ; \mathrm{H}, 5.3 ; \mathrm{N}, 5.9 . v_{\max } / \mathrm{cm}^{-1}: 1606(\mathrm{C}=\mathrm{N}), 1536$ $(\mathrm{C}=\mathrm{C}), 1094$ and $623\left(\mathrm{ClO}_{4}^{-}\right)$. MS $(\mathrm{FAB}+)[\mathrm{m} / \mathrm{z}(\% \mathrm{BPI})]: 787$ $(100 \%)\left[\mathrm{Eu}\left(\mathbf{L}^{2}-2 \mathrm{H}\right)\right]^{+} . \Lambda_{\mathrm{M}}$ (acetonitrile): $113 \mathrm{~cm}^{2} \Omega^{-1} \mathrm{~mol}^{-1}(1: 1$ electrolyte).

[Gd( $\left.\left.\mathbf{L}^{2}-\mathbf{2 H}\right)\right]\left(\mathbf{C l O}_{4}\right) \cdot \mathbf{C}_{3} \mathbf{H}_{7} \mathbf{O} \cdot \mathbf{0 . 5} \mathbf{H}_{2} \mathbf{O}$ (7). Yield: $0.038 \mathrm{~g}, 34 \%$. Anal. Found: C, 51.2; $\mathrm{H}, 5.3 ; \mathrm{N}, 5.8$. Calcd for $\mathrm{C}_{38} \mathrm{H}_{42} \mathrm{ClGdN}_{4} \mathrm{O}_{9}$. $\mathrm{C}_{3} \mathrm{H}_{7} \mathrm{O}: \mathrm{C}, 51.3 ; \mathrm{H}, 5.3 ; \mathrm{N}, 5.8 . v_{\max } / \mathrm{cm}^{-1}: 1607(\mathrm{C}=\mathrm{N}), 1536$ $(\mathrm{C}=\mathrm{C}), 1094$ and $623\left(\mathrm{ClO}_{4}^{-}\right)$. MS $(\mathrm{FAB}+)[\mathrm{m} / \mathrm{z}(\% \mathrm{BPI})]: 789$ (100\%) $\left[\mathrm{Gd}\left(\mathbf{L}^{2}-2 \mathrm{H}\right)\right]^{+} . \Lambda_{\mathrm{M}}$ (acetonitrile): $144 \mathrm{~cm}^{2} \Omega^{-1} \mathrm{~mol}^{-1}(1: 1$ electrolyte).

[Tb( $\left.\left.\mathbf{L}^{2}-\mathbf{2 H}\right)\right]\left(\mathbf{C l O}_{4}\right)(\mathbf{8})$. Yield: $0.038 \mathrm{~g}, 38 \%$. Anal. Found: C, 51.1; H, 4.7; N, 6.3. Calcd for $\mathrm{C}_{38} \mathrm{H}_{42} \mathrm{ClN}_{4} \mathrm{O}_{9} \mathrm{~Tb} \cdot \mathrm{H}_{2} \mathrm{O}: \mathrm{C}, 51.1 ; \mathrm{H}$, 4.7; N, 6.3. $v_{\max } / \mathrm{cm}^{-1}$ : $1609(\mathrm{C}=\mathrm{N}), 1538(\mathrm{C}=\mathrm{C}), 1116$ and 622 $\left(\mathrm{ClO}_{4}^{-}\right)$. MS (FAB+) $[\mathrm{m} / \mathrm{z}(\% \mathrm{BPI})]: 793(100 \%)\left[\mathrm{Tb}\left(\mathbf{L}^{2}-2 \mathrm{H}\right)\right]^{+}$.

$\left[\mathrm{Dy}\left(\mathrm{L}^{2}-\mathbf{2 H}\right)\right]\left(\mathrm{ClO}_{4}\right) \cdot \mathbf{C}_{3} \mathbf{H}_{7} \mathbf{O}$ (9). Yield: $0.092 \mathrm{~g}, 82 \%$. Anal. Found: $\mathrm{C}, 51.2 ; \mathrm{H}, 4.9 ; \mathrm{N}$, 5.7. Calcd for $\mathrm{C}_{38} \mathrm{H}_{42} \mathrm{ClDyN}_{4} \mathrm{O}_{9}$. $\mathrm{C}_{3} \mathrm{H}_{7} \mathrm{O}: \mathrm{C}, 51.5 ; \mathrm{H}, 5.3 ; \mathrm{N}, 5.9 . v_{\max } / \mathrm{cm}^{-1}: 1609(\mathrm{C}=\mathrm{N}), 1538$ $(\mathrm{C}=\mathrm{C}), 1116$ and $622\left(\mathrm{ClO}_{4}^{-}\right)$. MS $(\mathrm{FAB}+)[\mathrm{m} / \mathrm{z}(\% \mathrm{BPI})]: 798$ (100\%) $\left[\mathrm{Dy}\left(\mathbf{L}^{2}-2 \mathrm{H}\right)\right]^{+} . \Lambda_{\mathrm{M}}$ (acetonitrile): $118 \mathrm{~cm}^{2} \Omega^{-1} \mathrm{~mol}^{-1}(1: 1$ electrolyte).

$\left[\mathbf{H o}\left(\mathbf{L}^{2}-\mathbf{2 H}\right)\right]\left(\mathbf{C l O}_{4}\right) \cdot \mathbf{H}_{2} \mathbf{O} \cdot \mathbf{C}_{3} \mathbf{H}_{7} \mathbf{O}(\mathbf{1 0})$. Yield: $0.030 \mathrm{~g}, 26 \%$. Anal. Found: C, 50.6; H, 5.2; N, 5.8. Calcd for $\mathrm{C}_{38} \mathrm{H}_{42} \mathrm{ClHoN}_{4} \mathrm{O}_{9}$. $\mathrm{H}_{2} \mathrm{O} \cdot \mathrm{C}_{3} \mathrm{H}_{7} \mathrm{O}: \mathrm{C}, 50.4 ; \mathrm{H}, 5.4 ; \mathrm{N}$, 5.7. $v_{\max } / \mathrm{cm}^{-1}: 1607(\mathrm{C}=\mathrm{N})$, $1536(\mathrm{C}=\mathrm{C}), 1095$ and $623\left(\mathrm{ClO}_{4}^{-}\right)$. MS $(\mathrm{FAB}+)[\mathrm{m} / \mathrm{z}(\% \mathrm{BPI})]$ : $799(100 \%)\left[\mathrm{Ho}\left(\mathbf{L}^{2}-2 \mathrm{H}\right)\right]^{+} . \Lambda_{\mathrm{M}}$ (acetonitrile): $125 \mathrm{~cm}^{2} \Omega^{-1} \mathrm{~mol}^{-1}$ (1:1 electrolyte).

Measurements. Elemental analyses were carried out on a Carlo Erba 1108 elemental analyzer. FAB mass spectra were recorded using a Fisons Quatro mass spectrometer with $\mathrm{Cs}$ ion gun and thioglycerol matrix. ${ }^{1} \mathrm{H}$ and ${ }^{13} \mathrm{C}$ NMR spectra were run at $20{ }^{\circ} \mathrm{C}$ with Bruker AC200 F, Bruker AMX300, and Varian Unity-500 spectrometers operating respectively at 200.13, 300.130, and 499.824 MHz for ${ }^{1} \mathrm{H}$ and 50.366, 75.533, and $125.789 \mathrm{MHz}$ for ${ }^{13} \mathrm{C}$. Chemical shifts are reported in parts per million with respect to TMS. Longitudinal ${ }^{1} \mathrm{H}$ relaxation times $T_{1}$ were measured by the inversion-recovery pulse sequence. ${ }^{21}$ Spectral assignments were based in part on two-dimensional COSY, HMQC and HMBC experiments. IR spectra were recorded, as $\mathrm{KBr}$ disks, using a Bruker Vector 22 spectrophotometer. Conductivity measurements were carried out at $20^{\circ} \mathrm{C}$ with a Crison Micro CM 2201 conductimeter using $10^{-3} \mathrm{M}$ solutions of the complexes in acetonitrile. Electronic

(21) Vold, R. V.; Waugh, J. S.; Klein, M. P.; Phelps, D. E. J. Chem. Phys. 1968, 48,3831 .
Table 1. Crystal Data and Structure Refinement for $\mathbf{2}$ and $\mathbf{5 b}$

\begin{tabular}{|c|c|c|}
\hline & 2 & $5 \mathbf{b}$ \\
\hline formula & $\mathrm{C}_{38} \mathrm{H}_{42.5} \mathrm{CeClN}_{4} \mathrm{O}_{9.25}$ & $\mathrm{C}_{41} \mathrm{H}_{50} \mathrm{ClN}_{4} \mathrm{O}_{10} \mathrm{Sm}$ \\
\hline$M_{\mathrm{r}}$ & 878.83 & 944.65 \\
\hline cryst system & monoclinic & monoclinic \\
\hline space group & $P 2_{1} / c$ & $P 2_{1} / n$ \\
\hline$T / \mathrm{K}$ & $293(2)$ & $298(2)$ \\
\hline$a / \AA ̊$ & $25.5382(4)$ & $16.5413(2)$ \\
\hline$b / \AA$ & $11.6407(2)$ & $14.3782(2)$ \\
\hline$c / \AA$ & $27.6814(6)$ & $17.8293(2)$ \\
\hline$\beta / \mathrm{deg}$ & 110.70 & 98.28 \\
\hline$V / \AA^{3}$ & $7697.8(2)$ & $4196.18(9)$ \\
\hline$F_{000}$ & 3580 & 1932 \\
\hline $\mathrm{Z}$ & 8 & 4 \\
\hline$D_{\text {cald }} / \mathrm{g} \mathrm{cm}^{-3}$ & 1.517 & 1.495 \\
\hline$\mu / \mathrm{mm}^{-1}$ & 1.312 & 1.524 \\
\hline $\mathrm{R}_{\text {int }}$ & 0.1249 & 0.0579 \\
\hline reflcns measd & 50048 & 27258 \\
\hline reflcns obsd & 8353 & 6330 \\
\hline goodness-of-fit on $F^{2}$ & 1.061 & 1.054 \\
\hline $\mathrm{R}_{1}^{a}$ & 0.0958 & 0.0550 \\
\hline $\mathrm{wR}_{2}$ (all data) ${ }^{b}$ & 0.1873 & 0.1139 \\
\hline
\end{tabular}

spectra in the UV-vis range were recorded at $20{ }^{\circ} \mathrm{C}$ on a PerkinElmer Lambda 900 UV - vis spectrophotometer using $1.0 \mathrm{~cm}$ quartz cells. Reflectance spectra were recorded on a Perkin-Elmer Lambda 900 spectrometer equipped with a biconical diffuse reflectance PELA-1022 accessory.

The experimental details for high-resolution laser excited luminescence measurements were previously described. ${ }^{15}$ Lifetimes are averages of at least 3-5 independent determinations. Ligand excitation and emission spectra were recorded on a Perkin-Elmer LS-50B spectrometer equipped for low temperature $(77 \mathrm{~K})$ measurements. Absolute quantum yields were calculated relative to quinine sulfate in dilute sulfuric acid (absolute quantum yield: $0.546)^{22}$ or cresol violet (absolute quantum yield: 0.52$){ }^{23}$

X-ray Crystal Structure Determinations. Crystal data and details on data collection and refinement are summarized in Table 1. Three-dimensional, room-temperature $\mathrm{X}$-ray data were collected in the $\theta$ range $0.85-28.27^{\circ}(\mathbf{2})$ and $1.57-28.30^{\circ}(\mathbf{5 b})$ on a Bruker Smart 1000 CCD instrument. Reflections were measured from a hemisphere of data collected from frames each of them covering $0.3^{\circ}$ in $\omega$. Of the $50048(\mathbf{2})$ and $27258(\mathbf{5 b})$ reflections measured, all of which were corrected for Lorentz and polarization effects and for absorption by semiempirical methods on the basis of symmetry-equivalent and repeated reflections, 8353 (2) and 6330 (5b) independent reflections exceeded the significance level $(|F| /$ $\sigma|F|)>4.0$. The structures were solved by direct methods and refined by full-matrix least squares on $F^{2}$. Hydrogen atoms were included in calculated positions and refined in the riding mode. Refinement was performed with allowance for thermal anisotropy of all non-hydrogen atoms in $\mathbf{2}$ and $\mathbf{5 b}$ except for the atoms $\mathrm{O}(1 \mathrm{~W})$ in 2 and $\mathrm{C}(1 \mathrm{~S}), \mathrm{C}(2 \mathrm{~S}), \mathrm{C}(3 \mathrm{~S})$, and $\mathrm{O}(1 \mathrm{~S})$ of the 2-propanol group in $\mathbf{5 b}$. The crystal of $\mathbf{2}$ presents two complex salts in the asymmetric unit and presents a disorder in one ionic perchlorate. This disorder has been resolved, and two atomic sites for $\mathrm{O}(11), \mathrm{O}(12)$, and $\mathrm{O}(13)$ atoms of the perchlorate ion have been observed and refined with anisotropic atomic displacement parameters. The sites occupancy factor was 0.59308 for $\mathrm{Cl}(2 \mathrm{~A}), \mathrm{O}(11 \mathrm{~A}), \mathrm{O}(12 \mathrm{~A})$, and $\mathrm{O}(13 \mathrm{~A})$. The crystal of $\mathbf{5 b}$ presents a disorder in the carbon atoms around the amine nitrogen atom, $\mathrm{N}(2)$, and in two oxygen atoms in the

(22) Meech, S. R.; Philips, D. J. J. Photochem. 1983, 23, 193.

(23) Magde, D.; Brannon, J. H.; Cremers, T. L.; Olmsted, J. J. Phys. Chem. 1979, 83, 696 .

6948 Inorganic Chemistry, Vol. 42, No. 21, 2003 
perchlorate ion. These disorders have been resolved, and two atomic sites for $\mathrm{C}(6), \mathrm{C}(10)$, and $\mathrm{C}(11)$, around the $\mathrm{N}(2)$ atom, and for $\mathrm{O}(6)$ and $\mathrm{O}(9)$, in the perchlorate ion, have been observed and refined with anisotropic atomic displacement parameters. The sites occupancy factors were 0.57604 for $\mathrm{C}(6 \mathrm{~A}), \mathrm{C}(10 \mathrm{~A})$, and $\mathrm{C}(11 \mathrm{~A})$ and 0.62841 for $\mathrm{O}(6 \mathrm{~A})$ and $\mathrm{O}(9 \mathrm{~A})$. Minimum and maximum final electronic densities of -0.742 and 1.169 e $\AA^{3}$ for 2 and -0.697 and $0.544 \mathrm{e} \AA^{3}$ for $\mathbf{5 b}$ were found. Complex scattering factors were taken from the program package SHELXTL ${ }^{24}$ as implemented on a Pentium computer.

\section{Results and Discussion}

Synthesis and Characterization. Reaction of $\mathbf{L}^{2}$ [prepared in situ by the condensation of $N, N^{\prime}$-bis(2-aminobenzyl)-1,10diaza-15-crown-5 and salicylaldehyde] with triethylamine and the corresponding hydrated lanthanide perchlorate in 2-propanol led to complexes of formula $\left[\mathrm{Ln}\left(\mathbf{L}^{2}-2 \mathrm{H}\right)\right]\left(\mathrm{ClO}_{4}\right)$. $x \mathrm{H}_{2} \mathrm{O} \cdot y \mathrm{C}_{3} \mathrm{H}_{8} \mathrm{O}(\mathrm{Ln}=\mathrm{La}-\mathrm{Ho})$ in $24-86 \%$ yield. The IR and FAB-mass spectra of the complexes confirmed the formation of the Schiff-base lariat ether and its presence in the complexes. The IR spectra ( $\mathrm{KBr}$ disks) feature a band attributable to $v(\mathrm{C}=\mathrm{N})_{\text {imine }}$ stretching mode at ca. $1608 \mathrm{~cm}^{-1}$. The presence of this band together with the absence of bands due to carbonyl and/or amine vibration modes confirms the formation of the imine. Bands corresponding to the $v_{\text {as }}(\mathrm{Cl}-$ O) stretching and $\delta_{\text {as }}(\mathrm{O}-\mathrm{Cl}-\mathrm{O})$ bending modes of the perchlorate groups appear at ca. 1100 and $630 \mathrm{~cm}^{-1} .{ }^{25}$ The absorption at $630 \mathrm{~cm}^{-1}$ clearly shows up without splitting, as befits an uncoordinated anion. The FAB-mass spectrum of each complex displays a very intense peak (100\% BPI) corresponding to the $\left[\operatorname{Ln}\left(\mathbf{L}^{2}-2 \mathrm{H}\right)\right]^{+}$fragment. The molar conductivity values, as measured in ca. $10^{-3} \mathrm{M}$ acetonitrile solutions of the complexes, fall in the range generally accepted for 1:1 electrolytes in this solvent, ${ }^{26}$ suggesting that the perchlorate anion is not coordinated to the $\mathrm{Ln}$ (III) ion in acetonitrile solution.

$\mathbf{X}$-ray Structures of $\mathbf{2}$ and $\mathbf{5 b}$. Crystals of $\mathbf{2}$ and $\mathbf{5 b}$ consist of $\left[\mathrm{Ce}\left(\mathbf{L}^{2}-2 \mathrm{H}\right)\right]^{+}$and $\left[\mathrm{Sm}\left(\mathbf{L}^{2}-2 \mathbf{H}\right)\right]^{+}$cations, respectively, and one well-separated perchlorate anion; crystal lattices also contain solvent and water molecules. Complex 2 crystallizes in the monoclinic space group $P 2_{1} / c$, and the asymmetric unit contains two different $\left[\mathrm{Ce}\left(\mathbf{L}^{2}-2 \mathrm{H}\right)\right] \mathrm{ClO}_{4}$ complex salts with slightly different bond distances and angles. Complex $\mathbf{5 b}$ crystallizes in the monoclinic space group $P 2{ }_{1} / n$, but the asymmetric unit contains a single [Sm-

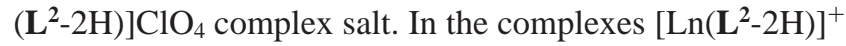
$(\mathrm{Ln}=\mathrm{Ce}, \mathrm{Sm})$, the corresponding lanthanide ion is bound to the nine available donor atoms of the bibracchial lariat ether as shown in Figure 1. Table 2 summarizes selected bond lengths, while selected bond angles are given in Table $\mathrm{S} 1$ (Supporting Information). Most of the $\mathrm{Ln}-\mathrm{X}(\mathrm{X}=\mathrm{O}$, $\mathrm{N})$ distances are standard.$^{27} \mathrm{We}$ have noticed that the $\mathrm{Ce}-\mathrm{X}$ distances are very similar to those found for $\left[\mathrm{Ce}\left(\mathbf{L}^{1}-2 \mathrm{H}\right)\right]^{+},{ }^{18}$

(24) Sheldrick, G. M. SHELXTL Bruker Analytical X-ray System, release 5.1; Bruker: Madison, WI, 1997.

(25) Nakamoto, K. In Infrared and Raman Spectra of Inorganic and Coordination Compounds, 3rd ed.; J. Wiley: New York, Chichester, Brisbane, and Toronto, 1972; pp 142-154.

(26) Geary, W. J. Coord. Chem. Rev. 1971, 7, 81.
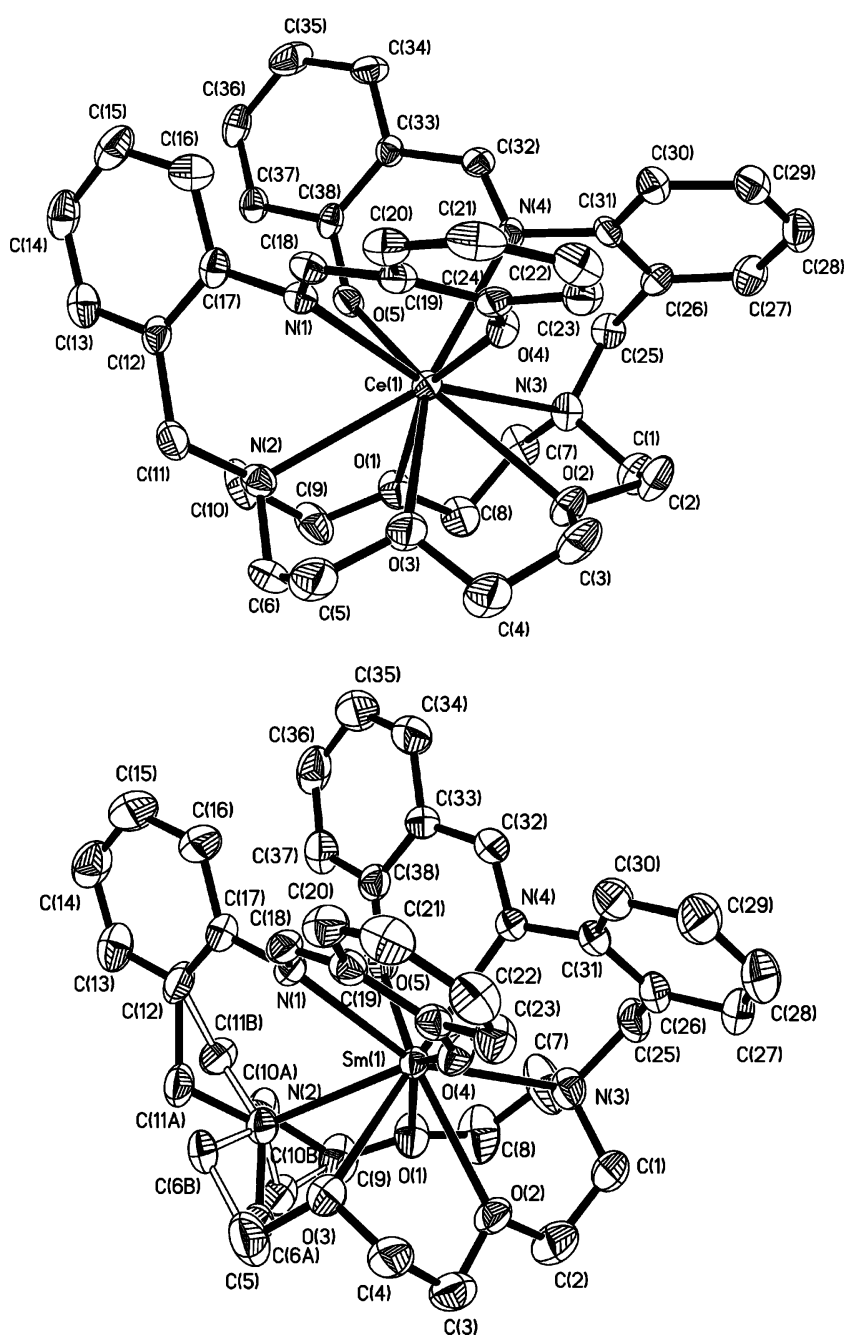

Figure 1. Crystal structures of $\left[\mathrm{Ce}\left(\mathbf{L}^{2}-2 \mathrm{H}\right)\right]^{+}$(top, $\Lambda$ optical isomer) and $\left[\mathrm{Sm}\left(\mathbf{L}^{2}-2 \mathrm{H}\right)\right]^{+}$(botton, $\Lambda$ optical isomer). Hydrogen atoms are omitted for simplicity. The ORTEP plot is at the $30 \%$ probability level.

Table 2. Selected Bond Lengths $(\AA)$ for Complexes 2 and $\mathbf{5 b}$

\begin{tabular}{|c|c|c|c|c|c|}
\hline \multicolumn{2}{|c|}{2} & \multicolumn{2}{|l|}{2} & \multicolumn{2}{|l|}{$5 b$} \\
\hline $\mathrm{Ce}(1)-\mathrm{O}(1)$ & $2.593(7)$ & $\mathrm{Ce}(2)-\mathrm{O}(6)$ & $2.587(7)$ & $\mathrm{Sm}(1)-\mathrm{O}(1)$ & 2.552( \\
\hline $\mathrm{Ce}(1)-\mathrm{O}(2)$ & $2.701(7)$ & $\mathrm{Ce}(2)-\mathrm{O}(7)$ & $2.722(7)$ & $\mathrm{Sm}(1)-\mathrm{O}(2)$ & $336(3)$ \\
\hline $\mathrm{Ce}(1)-\mathrm{O}(3)$ & $2.686(7)$ & $\mathrm{Ce}(2)-\mathrm{O}(8)$ & $2.704(7)$ & $\mathrm{Sm}(1)-\mathrm{O}(3)$ & $2.808(4)$ \\
\hline $\mathrm{Ce}(1)-\mathrm{O}(4)$ & $2.300(7)$ & $\mathrm{Ce}(2)-\mathrm{O}(9)$ & $2.297(6)$ & $\mathrm{Sm}(1)-\mathrm{O}(4)$ & $2.224(3)$ \\
\hline $\mathrm{Ce}(1)-\mathrm{O}(5)$ & $2.287(6)$ & $\mathrm{Ce}(2)-\mathrm{O}(10)$ & $2.297(6)$ & $\mathrm{Sm}(1)-\mathrm{O}(5)$ & $2.258(4)$ \\
\hline $\mathrm{Ce}(1)-\mathrm{N}(1)$ & $2.687(8)$ & $\mathrm{Ce}(2)-\mathrm{N}(5)$ & $2.638(7)$ & $\mathrm{Sm}(1)-\mathrm{N}(1)$ & $2.604(4)$ \\
\hline$(1)-N(2)$ & $2.802(8)$ & $\mathrm{Ce}(2)-\mathrm{N}(6)$ & $2.919(8)$ & $\mathrm{Sm}(1)-\mathrm{N}(2)$ & $2.663(4)$ \\
\hline $\mathrm{Ce}(1)-\mathrm{N}(3)$ & $2.984(8)$ & $\mathrm{Ce}(2)-\mathrm{N}(7)$ & $2.822(8)$ & $\mathrm{Sm}(1)-\mathrm{N}(3)$ & $2.757(4)$ \\
\hline $\mathrm{Ce}(1)-\mathrm{N}(4)$ & $2.644(7)$ & $\mathrm{Ce}(2)-\mathrm{N}(8)$ & $2.685(8)$ & $\operatorname{Sm}(1)-N(4)$ & $2.580(4)$ \\
\hline
\end{tabular}

except for the distances between the lanthanide ion and both pivotal nitrogen atoms, which are considerably shorter in the case of $\mathbf{2}$. This is probably a consequence of the smaller

(27) Rogers, R. D.; Rollins, A. N.; Benning, M. M. Inorg. Chem. 1988, 27, 3826. Rogers, R. D.; Rollins, A. N.; Etzenhouser, R. D.; Voss, E. J.; Baner, C. B. Inorg. Chem. 1993, 32, 3451. Lee, T. J.; Shen, H.-R.; Chin, T. I.; Chang, C. T. Acta Crystallogr., Sect. C 1983, 39, 1357. Rogers, R. D.; Kiruhara, L. K. Inorg. Chem. 1987, 26, 1498. Burns, J. H. Inorg. Chem. 1979, 18, 3044. Spodine, E.; Moreno, V.; Garland, M. T.; Pena, O.; Baggio, R. Inorg. Chim. Acta 2000, 309, 57. Terzis, A.; Mentzafos, D.; Tajmir-Riahi, H. A. Inorg. Chim. Acta 1984, 84, 187. Howell, R. C.; Spence, K. V. N.; Kahwa, I. A.; Williams, D. J. J. Chem. Soc., Dalton Trans. 1998, 2727. Bernhardt, P. V.; Flanagan, B. M.; Riley, M. J. Aust. J. Chem. 2000, 53, 229. 
González-Lorenzo et al.

ring size of the ligand, which allows the pivotal nitrogen atoms to approach the $\mathrm{Ln}$ ion.

Figure 1 allows an appraisal of the conformation adopted by the bibracchial lariat ether in $\mathbf{2}$ and $\mathbf{5 b}$. Both sidearms are on the same side of the crown moiety, resulting in a syn conformation. Likewise, the lone pair of both pivotal nitrogen atoms is directed inward the receptor cavity in an endoendo arrangement. It must be pointed out that the syn conformation adopted by the lariat ether leads to a chiral structure for the complex with two possible optical isomers, labeled $\Lambda$ or $\Delta$, indicating either left-handed $(\Lambda)$ or righthanded $(\Delta)$ structural chirality about the 2-fold symmetry axis of the complex. Inspection of the crystal structure data reveals that $\mathbf{2}$ and $\mathbf{5 b}$ crystallize as racemates. The two aromatic rings containing $\mathrm{C}(12)$ and $\mathrm{C}(33)$ are nearly parallel, and the coordination of both sidearms to the $\mathrm{Ln}$ (III) ion brings the two aromatic rings close together so that intramolecular $\pi-\pi$ interactions are possible. ${ }^{28-30}$ The distance between the center of both rings is $3.967 \AA$ for the cation complex containing $\mathrm{Ce}(1)$ and $3.816 \AA$ for the cation complex containing $\mathrm{Ce}(2)$, and the dihedral angles between the least-squares planes are 15.7 and $12.4^{\circ}$, respectively. For $\mathbf{5 b}$, the distance between the center of both rings is $3.962 \AA$ and the dihedral angle between the least-squares planes amounts to $16.7^{\circ}$. These data demonstrate that the electronrich phenol ring containing $\mathrm{C}(33)$ overlaps the electrondeficient benzyl ring containing $\mathrm{C}(12)$, which results in a cryptand-like structure due to the formation of a second pseudomacrocycle. Similar $\pi-\pi$ stacking interactions were observed for a $\mathrm{Ba}(\mathrm{II})$ complexes with a 18-crown-6 ligand bearing two 5-chloro-8-hydroxyquinoline units. ${ }^{28}$

The coordination polyhedron around the lanthanide ion may be described as a distorted monocapped square antiprism comprised of two parallel pseudo planes: $\mathrm{O}(1), \mathrm{O}(3), \mathrm{O}(5)$, and $\mathrm{N}(1)$ define the upper pseudoplane while $\mathrm{O}(2), \mathrm{O}(4)$, $\mathrm{N}(3)$, and $\mathrm{N}(4)$ define the lower pseudoplane, $\mathrm{N}(2)$ capping the upper plane (Figure 2). The degree of distortion of the bicapped square antiprisms has been investigated quantitatively using a geometric analysis on the basis of the determination of three angles, $\phi, \theta_{\mathrm{i}}$, and $\omega_{\mathrm{i}}$ (Figure 3). ${ }^{31}$ The average bending of the upper $(\operatorname{vs}(j))$ and lower $(\operatorname{vi}(j))$ pseudoplanes is measured by the angle $\phi$ between the sum vectors $\mathbf{R}_{\mathbf{1}}$ and $\mathbf{R}_{\mathbf{2}}\left(\mathbf{R}_{\mathbf{1}}=\sum_{j=1}^{4} \mathbf{L n}-\mathbf{v s}(j), \mathbf{R}_{\mathbf{2}}=\sum_{j=1}^{4} \mathbf{L n}-\right.$ $\mathbf{v i}(j)$, and $\phi=180^{\circ}$ for an ideal square antiprism), while the angles $\theta_{\mathrm{i}}$ reflect the flattening of the coordination polyhedron along the pseudo- $C_{4}$ axis. Finally, the angles $\omega_{\mathrm{i}}$ show the deformation of the coordination polyhedron from a square antiprism (ideal value $45^{\circ}$ ) toward a square prism (ideal value $0^{\circ}$ ). In both $\mathbf{2}$ and $\mathbf{5 b}$ complexes the $\phi$ angle does not deviate much from the expected value for a perfect square antiprism

(28) Zhang, X.-X.; Boedunov, A. V.; Bradshaw, J. S.; Dalley, N. K.; Kou, X.; Izatt, R. M. J. Am. Chem. Soc. 1995, 117, 11507.

(29) Ranganathan, D.; Haridas, V.; Gilardi, R.; Karle, I. L. J. Am. Chem. Soc. 1998, 120, 10793.

(30) Lahiri, S.; Thompson, J. L.; Moore, J. S. J. Am. Chem. Soc. 2000, $122,11315$.

(31) Piguet, C.; Bünzli, J.-C. G.; Bernardinelli, G.; Bochet C. G.; Froidevaux, P. J. Chem. Soc., Dalton Trans. 1995, 83. Elhabiri, M.; Scopelliti, R.; Bünzli, J.-C. G.; Piguet, C. J. Am. Chem. Soc. 1999, 121, 10747.

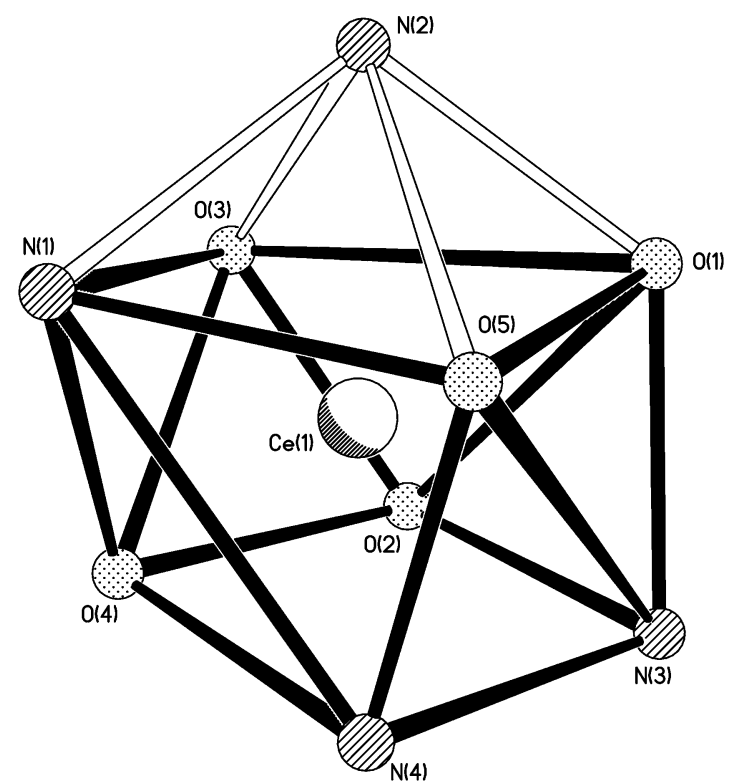

Figure 2. View of the coordination polyhedron in $\left[\mathrm{Ce}\left(\mathbf{L}^{2}-2 \mathrm{H}\right)\right]^{+}$.
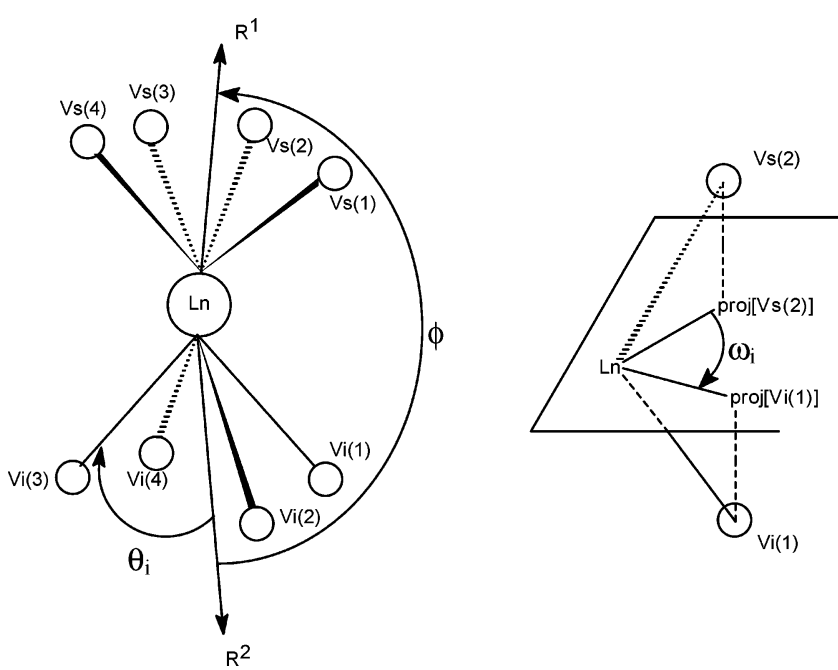

Figure 3. Definition of the angles and vectors used in the analysis of a square antiprism coordination polyhedron.

(Table 3), disregarding the different nature of the donor atoms of the ligand. This indicates a small bending of the upper and lower facial planes, which is also confirmed by their almost parallel arrangement (Table 3 ). The $\theta_{\mathrm{i}}$ values between the $\mathbf{R}_{\mathbf{1}}$ and the vs vectors are in general larger than those formed between $\mathbf{R}_{\mathbf{2}}$ and the vi vectors for both complexes as a consequence of the unsymmetrical position of the Ln ion into the coordination polyhedron, probably because the capping atom "pulls" the lanthanide ion closer to the upper plane (Table 3 ). Finally, the mean $\omega_{\mathrm{i}}$ angles are very close to the ideal values of $45^{\circ}$ expected for a square antiprism (Table 3).

${ }^{1} \mathrm{H}$ and ${ }^{13} \mathrm{C}$ NMR spectra. The ${ }^{1} \mathrm{H}$ and ${ }^{13} \mathrm{C}$ NMR spectra of the La(III) diamagnetic complex $\mathbf{1}$ were recorded in acetonitrile- $d_{3}$ solution and assigned on the basis of twodimensional COSY, HMQC, and HMBC experiments at 293 K (Table 4; see Figure 1 for the numbering scheme). The anionic nature of the receptor is confirmed by the absence of signal due to the phenolic protons. Both the ${ }^{1} \mathrm{H}$ 
Table 3. Geometric Analysis of the Coordination Polyhedra in 2 and $5 b$

\begin{tabular}{|c|c|c|c|}
\hline & $\mathbf{2}^{a}$ & $\mathbf{2}^{b}$ & $5 b$ \\
\hline$\alpha / \mathrm{deg}^{c}$ & 9.6 & 10.6 & 12.4 \\
\hline$d^{1} / \AA^{d}$ & 0.1591 & 0.1628 & 0.0937 \\
\hline$d^{2} / \AA^{e}$ & 0.0258 & 0.0016 & 0.0967 \\
\hline$d^{3} / \AA^{f}$ & 2.590 & 2.560 & 2.38 \\
\hline$d^{4} / \AA^{g}$ & 1.871 & 1.898 & 1.64 \\
\hline$d^{5} / \AA^{h}$ & 0.9630 & 0.9567 & 0.9431 \\
\hline$d^{6} / \AA^{i}$ & 1.5753 & 1.5539 & 1.4549 \\
\hline$\phi /$ deg & 170.5 & 171.0 & 172.8 \\
\hline mean $\theta \mathbf{v s}_{\mathrm{i}}-\mathbf{R}_{1} / \mathrm{deg}$ & 67.9 & 68.1 & 67.9 \\
\hline mean $\theta \mathbf{v s}_{\mathbf{i}}-\mathbf{R}_{2} / \mathrm{deg}$ & 52.4 & 52.9 & 54.2 \\
\hline mean $\omega \mathbf{v} \mathbf{s}_{\mathbf{i}}-\mathbf{v} \mathbf{i}_{i} / \operatorname{deg}$ & 45.7 & 45.6 & 44.9 \\
\hline
\end{tabular}

${ }^{a}$ Data corresponding to the cation containing Ce(1). ${ }^{b}$ Data corresponding to the cation containing $\mathrm{Ce}(2) .{ }^{c}$ Angle between the upper and lower facial planes. ${ }^{d}$ Mean deviation from planarity of the upper facial plane. ${ }^{e}$ Mean deviation from planarity of the lower facial plane. ${ }^{f}$ Distance between the upper and lower facial planes. ${ }^{g}$ Distance between N(2) and the upper plane. ${ }^{h}$ Distance between Ln and the upper plane. ${ }^{i}$ Distance between Ln and the lower plane.

and ${ }^{13} \mathrm{C}$ NMR spectra demonstrate that the complex presents a $C_{1}$ symmetry in acetonitrile solution, as in the solid state. Large low-frequency shifts have been described for aromatic protons of electron-deficient aromatic rings, which can still be further shifted by $\pi-\pi$ interactions between aromatic rings. ${ }^{28,32}$ This seems to be the situation for compound $\mathbf{1}$, for which the signal attributable to the aromatic proton $\mathrm{H} 16$ occurs at an unusually low frequency (5.66 ppm, Table 4). Therefore, the $\pi-\pi$ interactions observed in the solid state appear to operate also in acetonitrile solution. Since assignments to specific axial/equatorial $\mathrm{CH}_{2}$ protons were not possible on the basis of the 2D NMR spectra, they were carried out using the stereochemically dependent proton shift effects, resulting from the polarization of the $\mathrm{C}-\mathrm{H}$ bonds by the electric field generated by the cation charge, ${ }^{33}$ as predicted from the X-ray crystal structure of 5. This polarization results in a deshielding of the equatorial protons, which are pointing away from the metal ion.

For the Sm(III) complex $\mathbf{5}$, which displays relatively sharp signals, the ${ }^{1} \mathrm{H}$ (Figure 4) and ${ }^{13} \mathrm{C}$ NMR resonances from aromatic nuclei were assigned on the basis of twodimensional COSY, HMQC, and HMBC experiments (Table 4). Most pairs of geminal $\mathrm{CH}_{2}$ protons were identified because they give strong COSY cross-peaks (Figure S1, Supporting Information). A full assignment for the Sm(III) complex was carried out using the shift analysis method, ${ }^{34}$ and Cartesian coordinates were obtained from the X-ray crystal structure of 5b (Table 4; Figure 4). Proton spinlattice relaxation time $\left(T_{1}\right)$ measurements show that the proton signals corresponding to $\mathrm{CH}_{2}$ axial protons display $T_{1}$ values shorter than $0.20 \mathrm{~s}$, while the signals corresponding to equatorial protons present $T_{1}$ values ranging from 0.20 to $0.32 \mathrm{~s}$. These results suggest that the dipolar contribution to the proton spin-lattice relaxation rates is dominant in the present case, since this contribution should be proportional

(32) Sanders, J. K. M.; Hunter, B. K. Modern NMR Spectroscopy; Oxford University Press: Oxford, U.K., 1987.

(33) Harris, R. K. Nuclear Magnetic Resonance Spectroscopy: A Physicochemical View; Pitman: London, 1983.

(34) Forsberg, J. H.; Delaney, R. M.; Zhao, Q.; Harakas, G.; Chandran, R. Inorg. Chem. 1995, 34, 3705.
Table 4. ${ }^{1} \mathrm{H}$ and ${ }^{13} \mathrm{C}$ NMR Shifts ( $\delta$, with Respect to TMS) of Compounds $\mathbf{1}$ and $\mathbf{5}^{a}$

\begin{tabular}{|c|c|c|c|c|c|}
\hline${ }^{1} \mathrm{H}$ & $1^{b}$ & $5^{c}$ & ${ }^{13} \mathrm{C}$ & $1^{b}$ & $5^{c}$ \\
\hline $\mathrm{H} 1_{\mathrm{ax}}$ & 3.02 & -0.90 & $\mathrm{C} 1$ & 55.2 & 54.1 \\
\hline $\mathrm{H} 1_{\mathrm{eq}}$ & 3.02 & -1.02 & & & \\
\hline $\mathrm{H} 2_{\mathrm{ax}}$ & 3.43 & 1.43 & $\mathrm{C} 2$ & 70.8 & 72.8 \\
\hline $\mathrm{H} 2_{\mathrm{eq}}$ & 3.72 & 1.43 & & & \\
\hline $\mathrm{H} 3_{\mathrm{ax}}$ & 3.53 & 8.14 & C3 & 67.8 & 79.0 \\
\hline $\mathrm{H} 3_{\text {eq }}$ & 3.63 & 4.21 & & & \\
\hline $\mathrm{H} 4_{\mathrm{ax}}$ & 3.14 & 8.27 & $\mathrm{C} 4$ & 71.2 & 80.6 \\
\hline $\mathrm{H} 4_{\mathrm{eq}}$ & 4.32 & 4.82 & & & \\
\hline $\mathrm{H} 5_{\mathrm{ax}}$ & 3.53 & 2.14 & C5 & 70.4 & 70.4 \\
\hline $\mathrm{H} 5_{\mathrm{eq}}$ & 4.13 (b) & 2.82 & & & \\
\hline $\mathrm{H} 6_{\mathrm{ax}}$ & 2.28 & 5.47 & C6 & 53.4 & 64.2 \\
\hline $\mathrm{H} 6_{\mathrm{eq}}$ & 3.43 & 0.78 & & & \\
\hline $\mathrm{H} 7_{\mathrm{ax}}$ & $2.66(\mathrm{~d})$ & 1.43 & C7 & 59.1 & 60.0 \\
\hline $\mathrm{H} 7_{\mathrm{eq}}$ & 3.03 & -0.90 & & & \\
\hline $\mathrm{H} 8_{\mathrm{ax}}$ & 3.75 & 2.82 & $\mathrm{C} 8$ & 71.1 & 78.5 \\
\hline $\mathrm{H} 8_{\mathrm{eq}}$ & 4.25 & 5.48 & & & \\
\hline $\mathrm{H} 9_{\mathrm{ax}}$ & 3.63 & 5.31 & C9 & 70.5 & 80.7 \\
\hline $\mathrm{H} 9_{\mathrm{eq}}$ & 3.90 & 8.05 & & & \\
\hline $\mathrm{H} 10_{\mathrm{ax}}$ & $2.42(\mathrm{~d})$ & 7.84 & $\mathrm{C} 10$ & 53.7 & 62.7 \\
\hline $\mathrm{H} 10_{\mathrm{eq}}$ & 4.32 & 2.12 & & & \\
\hline $\mathrm{H} 11_{(1)}$ & 4.33 & $-0.28(\mathrm{~d})$ & $\mathrm{C} 11$ & 57.9 & 56.6 \\
\hline \multirow[t]{2}{*}{$\mathrm{H} 11_{(2)}$} & 3.90 & 1.09 & & & \\
\hline & & & $\mathrm{C} 12$ & 128.4 & d \\
\hline H13 & 7.29 (m) & $6.53(d)$ & $\mathrm{C} 13$ & 132.3 & 134.9 \\
\hline H14 & 7.09 (td) & $6.65(\mathrm{t})$ & $\mathrm{C} 14$ & 126.2 & 130.5 \\
\hline H15 & $6.92(\mathrm{~m})$ & $6.17(\mathrm{td})$ & $\mathrm{C} 15$ & 130.8 & 133.3 \\
\hline \multirow[t]{2}{*}{ H16 } & $5.66(\mathrm{~d})$ & 4.38 (d) & C16 & 122.1 & 125.0 \\
\hline & & & $\mathrm{C} 17$ & $d$ & $d$ \\
\hline \multirow[t]{2}{*}{ H18 } & $8.04(\mathrm{~s})$ & 4.64 & $\mathrm{C} 18$ & 169.7 & 172.7 \\
\hline & & & $\mathrm{C} 19$ & 123.3 & $\mathrm{~d}$ \\
\hline $\mathrm{H} 20$ & $7.29(\mathrm{~m})$ & $7.39(\mathrm{~m})$ & $\mathrm{C} 20$ & 137.4 & 143.8 \\
\hline $\mathrm{H} 21$ & $6.59(\mathrm{td})$ & $7.29(\mathrm{t})$ & $\mathrm{C} 21$ & 115.2 & 120.8 \\
\hline $\mathrm{H} 22$ & $7.29(\mathrm{~m})$ & $8.38(\mathrm{td})$ & $\mathrm{C} 22$ & 135.6 & 141.7 \\
\hline \multirow[t]{2}{*}{$\mathrm{H} 23$} & $6.10(\mathrm{~m})$ & $9.62(\mathrm{~d})$ & $\mathrm{C} 23$ & 121.9 & 127.1 \\
\hline & & & $\mathrm{C} 24$ & $d$ & $d$ \\
\hline $\mathrm{H} 25_{(1)}$ & 3.76 & -0.06 (d) & $\mathrm{C} 25$ & 62.9 & 64.1 \\
\hline \multirow[t]{2}{*}{$\mathrm{H} 25_{(2)}$} & $3.16(d)$ & 0.98 (d) & & & \\
\hline & & & $\mathrm{C} 26$ & 129.9 & $d$ \\
\hline $\mathrm{H} 27$ & 7.34 (dd) & $5.81(\mathrm{~d})$ & $\mathrm{C} 27$ & 130.9 & 133.6 \\
\hline $\mathrm{H} 28$ & $7.26(\mathrm{~m})$ & $6.88(\mathrm{t})$ & $\mathrm{C} 28$ & 126.1 & 129.7 \\
\hline H29 & $7.40(\mathrm{td})$ & $7.39(\mathrm{~m})$ & C29 & 130.8 & 135.4 \\
\hline \multirow[t]{2}{*}{$\mathrm{H} 30$} & $6.64(\mathrm{~d})$ & 8.94 (d) & C30 & 123.8 & 125.4 \\
\hline & & & C31 & $d$ & $d$ \\
\hline \multirow[t]{2}{*}{ H32 } & $7.90(\mathrm{~s})$ & 5.65 & C32 & 166.7 & 171.3 \\
\hline & & & C33 & 127.3 & d \\
\hline H34 & $7.14(\mathrm{dd})$ & $7.00(\mathrm{~d})$ & C34 & 135.7 & 140.9 \\
\hline H35 & $6.49(\mathrm{td})$ & $6.81(\mathrm{t})$ & C35 & 114.9 & 120.1 \\
\hline H36 & $6.92(\mathrm{~m})$ & $7.39(\mathrm{~m})$ & C36 & 135.1 & 140.7 \\
\hline \multirow[t]{2}{*}{ H37 } & $6.10(\mathrm{~m})$ & $6.72(d)$ & C37 & 122.6 & 126.8 \\
\hline & & & C38 & $d$ & $d$ \\
\hline
\end{tabular}

${ }^{a}$ See Figure 1 for numbering scheme. ${ }^{b}$ Conditions: assignment supported by 2D H,H COSY, HMQC, and HMBC experiments at $293 \mathrm{~K}$, $\mathrm{CD}_{3} \mathrm{CN}, 500 \mathrm{MHz} .{ }^{2} J_{7 \mathrm{eq}-7 \mathrm{ax}}=13.8 \mathrm{~Hz} ;{ }^{2} J_{10 \mathrm{eq}-10 \mathrm{ax}}=9.0 \mathrm{~Hz} ;{ }^{3} J_{14-13}=$ ${ }^{3} J_{14-15}=7.5 \mathrm{~Hz} ;{ }^{4} J_{14-16}=1.2 \mathrm{~Hz} ;{ }^{3} J_{16-15}=8.1 \mathrm{~Hz} ;{ }^{3} J_{21-20}={ }^{3} J_{21-22}=$ $7.3 \mathrm{~Hz} ;{ }^{2} J_{25 \mathrm{ax}-25 \mathrm{eq}}=12.2 \mathrm{~Hz} ;{ }^{3} J_{27-28}=7.1 \mathrm{~Hz} ;{ }^{4} J_{29-27}=J_{27-29}=1.2 \mathrm{~Hz}$; ${ }^{3} J_{30-29}=J_{29-30}=7.7 \mathrm{~Hz} ;{ }^{3} J_{34-35}=7.7 \mathrm{~Hz} ;{ }^{4} J_{34-36}=1.8 \mathrm{~Hz} .{ }^{c}$ Conditions: assignment supported by 2D H,H COSY, HMQC, and $\mathrm{HMBC}$ experiments at $293 \mathrm{~K}, \mathrm{CD}_{3} \mathrm{CN}, 500 \mathrm{MHz} .{ }^{2} J_{11-11}=12.9 \mathrm{~Hz} ;{ }^{2} J_{25-25}=11.8 \mathrm{~Hz} ;{ }^{3} J_{13-14}$ $=7.1 \mathrm{~Hz} ;{ }^{3} J_{14-13}={ }^{3} J_{14-15}=7.4 \mathrm{~Hz} ;{ }^{4} J_{15-13}=1.1 \mathrm{~Hz} ;{ }^{3} J_{15-14}={ }^{3} J_{15-16}$ $=7.5 \mathrm{~Hz} ;{ }^{3} J_{16-15}=7.9 \mathrm{~Hz} ;{ }^{3} J_{21-22}=7.0 \mathrm{~Hz} ;{ }^{4} J_{22-20}=1.9 \mathrm{~Hz} ;{ }^{3} J_{22-21}=$ ${ }^{3} J_{21-22}=7.5 \mathrm{~Hz} ;{ }^{3} J_{23-22}={ }^{3} J_{22-23}=8.5 \mathrm{~Hz} ;{ }^{3} J_{27-28}=6.6 \mathrm{~Hz} ;{ }^{3} J_{28-27}=$ $7.4 \mathrm{~Hz} ;{ }^{3} J_{28-29}=7.5 \mathrm{~Hz} ;{ }^{3} J_{30-29}=8.4 \mathrm{~Hz} ;{ }^{3} J_{34-35}=7.7 \mathrm{~Hz} ;{ }^{3} J_{35-34}=$ ${ }^{3} J_{35-36}=7.2 \mathrm{~Hz} ;{ }^{4} J_{34-36}=1.7 \mathrm{~Hz} ;{ }^{3} J_{37-36}=7.8 \mathrm{~Hz} .{ }^{d}$ Not observed.

to the inverse sixth power of the metal-proton distances and, hence, short relaxation times are expected for the protons located closer to the paramagnetic center. ${ }^{35} \mathrm{We}$ have explored the possibility to perform a more quantitative analysis of the

(35) Bertini, I.; Capozzi, F.; Luchinat, C.; Nicastro, G.; Xia, Z. J. Phys. Chem. 1993, 97, 6351. 
González-Lorenzo et al.

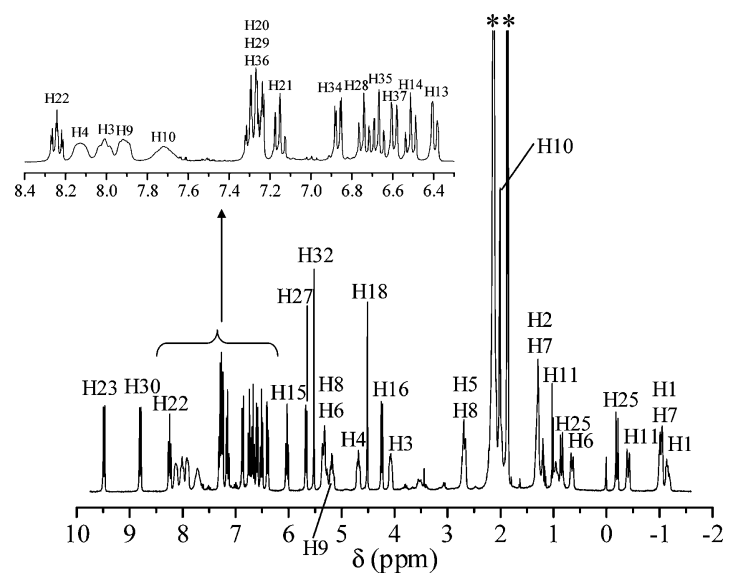

Figure 4. $500 \mathrm{MHz}{ }^{1} \mathrm{H}$ NMR spectrum of compound 5 as recorded in $\mathrm{CD}_{3} \mathrm{CN}$ solution at $293 \mathrm{~K}$. (See Figure 1 for labeling scheme.) Solvent signals are denoted with an asterisk.

structure of this complex in solution by using the Sm(III) paramagnetic induced shifts. Although such an analysis might be of limited value due to relatively small induced shifts with possibly some contact contributions, interesting information could be extracted from the data, which suggests that drastic differences between the solid state and solution structures, such as a different coordination number, do not occur. It also confirmed a very large magnetic anisotropy for this rhombic complex in solution.

The ${ }^{1} \mathrm{H}$ NMR spectra of the $\operatorname{Pr}(\mathrm{III}), \mathrm{Nd}(\mathrm{III})$, and $\mathrm{Eu}(\mathrm{III})$ complexes display 42 signals for the 42 nonexchangeable protons of the ligand (Table S2, Supporting Information), thereby confirming the absence of symmetry element. However, the assignment of the spectra of these compounds was not possible because the short relaxation times of the proton nuclei (e.g. the $T_{1}$ values measured for the $\mathrm{Eu}(\mathrm{III})$ complex 6 ranged between 28 and $760 \mathrm{~ms}$ ) prevented the observation of their COSY cross-peaks, except for a few relatively sharp proton signals that appear in the central part of the spectra. The short $T_{1}$ values observed for the $\mathrm{Eu}$ (III) complex indicate that all the proton nuclei are relatively close to the paramagnetic center, confirming that the whole set of the macrocyclic ligand donor atoms are bound to the metal ion in acetonitrile solution, the lanthanide ion being ninecoordinated. For the Tb(III), Dy(III), and Ho(III) complexes less than the expected 42 signals (between 22 for Dy(III) and 37 for Ho) are observed in the ${ }^{1} \mathrm{H}$ NMR spectra (Table S2, Supporting Information), probably as a consequence of the extreme line-broadening of some resonances. Some of these signals are extremely broad and probably correspond to axial protons of the crown moiety which are at 3.5-3.8 $\AA$ of the $\operatorname{Ln}(\mathrm{III})$ ion in the X-ray structure of $\mathbf{5 b}$, while other peaks are clearly sharper and probably correspond to aromatic protons of the ligand pendant arms. One notices Curie-spin effects on the line widths of the latter proton signals. ${ }^{36}$ For instance, the peaks observed in the spectrum of the Ho(III) complex at 75.5, 54.9, 51.0, and 32.6 ppm present line widths of 53.4, 49.6, 71.2, and $54.7 \mathrm{~Hz}$ at

(36) Aime, S.; Barbero, M.; Botta, M.; Ermondi, G. J. Chem. Soc., Dalton Trans. 1992, 225.
Table 5. Ligand-Centered Absorption and Emission Properties ${ }^{a}$

\begin{tabular}{ccclll}
\hline compd & $\pi \rightarrow \mathrm{p}^{* b}$ & $\pi \rightarrow \mathrm{p}^{* c}$ & ${ }^{1} \pi \pi^{* d}$ & ${ }^{3} \pi \pi^{* e}$ & $\tau\left({ }^{3} \pi \pi^{*}\right)^{e}$ \\
\hline \multirow{2}{*}{$\mathrm{Nd}$} & $42410(5.40)$ & 44190 & $f$ & $f$ & $f$ \\
& $36320(4.98)$ & 34300 & & & \\
\multirow{3}{*}{$\mathrm{Eu}$} & $27060(4.87)$ & 26430 & & $f$ & $f$ \\
& $42370(5.02)$ & 41600 & $f$ & $f$ & \\
& $36230(4.78)$ & 34340 & & & \\
$\mathrm{Gd}$ & $27030(4.48)$ & 26400 & & & \\
& $42920(5.24)$ & 44040 & 21320 & 18750 & $1.32(5)$ \\
& $36100(4.84)$ & 34240 & & 17630 & \\
& $26950(4.75)$ & 26350 & & 16440 &
\end{tabular}

${ }^{a}$ Energies are given in $\mathrm{cm}^{-1} \cdot{ }^{b}$ Electronic spectral data in acetonitrile at $295 \mathrm{~K}$; energies are given for the maximum of the band envelope in $\mathrm{cm}^{-1}$, and $\log \epsilon$ is given within parentheses. ${ }^{c}$ Reflectance spectra recorded at 295 K. ${ }^{d}$ Luminescence data in acetonitrile at $295 \mathrm{~K} .{ }^{e}$ Luminescence data and lifetimes (ms) in frozen acetonitrile solution at $77 \mathrm{~K} .{ }^{f}{ }^{3} \pi \pi^{*}$ luminescence quenched by transfer to the lanthanide ion.

$200 \mathrm{MHz}$, while at $500 \mathrm{MHz}$ the line widths are substantially enhanced, with values of $140.4,146.5,189.2$, and $152.6 \mathrm{~Hz}$, respectively. Although no specific assignments of the proton signals could be done, which prevented us from obtaining structural information, the spectra point again to a $C_{1}$ symmetry of the complexes in solution that is compatible with a nine-coordination of the $\mathrm{Ln}(\mathrm{III})$ ion.

The ${ }^{1} \mathrm{H}$ NMR spectra of these complexes $(\mathrm{Ln}=\mathrm{La}-\mathrm{Ho})$ remained unchanged for several weeks, demonstrating that di-deprotonated $\mathbf{L}^{2}$ forms stable complexes with these metal ions in acetonitrile solution. This contrasts with the behavior of the analogous $\mathbf{L}^{1}$ ligand, which forms stable complexes in acetonitrile solution only with the three lightest lanthanide ions ( $\mathrm{La}, \mathrm{Ce}$, and $\mathrm{Pr}),{ }^{18}$ probably as a consequence of the combination of the relatively large ring size of the crown moiety and the presence of relatively rigid pendant arms. The smaller ring size of $\mathbf{L}^{\mathbf{2}}$ compared to that of $\mathbf{L}^{\mathbf{1}}$ allows the formation of complexes with most of the $\operatorname{Ln}(\mathrm{III})$ ions $(\mathrm{Ln}=\mathrm{La}-\mathrm{Ho})$. The analogous complexes of $\mathbf{L}^{2}$ with the heaviest lanthanide ions $(\mathrm{Er}-\mathrm{Lu})$ could not be isolated. These results parallel previous potentiometric studies on lanthanide complexes with 18-crown-6 and 15-crown-5 derivatives, which demonstrated that the stability of the complexes decreases through the lanthanide series due to a better encapsulation of the larger ions into the cavity of the macrocycle. ${ }^{37}$

Photophysical Properties. Relevant photophysical data for the $\mathrm{Nd}, \mathrm{Eu}$, and $\mathrm{Gd}$ complexes are presented in Table 5. Electronic spectra of the complexes display three regions of absorption, a band centered around $27000 \mathrm{~cm}^{-1}$ typical of $\mathrm{C}=\mathrm{N}$ chromophores ${ }^{38}$ and two bands at ca. 36000 and $43000 \mathrm{~cm}^{-1}$ corresponding to $\mathrm{B}$ and $\mathrm{E}_{2} \pi-\pi^{*}$ transitions of the substituted aromatic rings, respectively. ${ }^{39}$ The fluorescence spectrum of the Gd(III) complex $\mathbf{7}$ in acetonitrile solution $(295 \mathrm{~K})$ presents a single band centered at ca. $21300 \mathrm{~cm}^{-1}$ (Figure 5) assigned to emission from the ${ }^{1} \pi \pi^{*}$ state. The absolute fluorescence quantum yield amounts to

(37) Massaux, J.; Desreux, J. F.; Delchambre, C.; Duyckaerts, G. Inorg. Chem. 1980, 19, 1893. Massaux, J.; Desreux, J. F. J. Am. Chem. Soc. 1982, 104, 2967.

(38) Aruna, V. A. J.; Alexander, V. J. Chem. Soc., Dalton Trans. 1996, 1867.

(39) Silverstein, R. M.; Bassler, C. Spectrometric Identification of Organic Compounds; Wiley Int.: New York, 1967. 


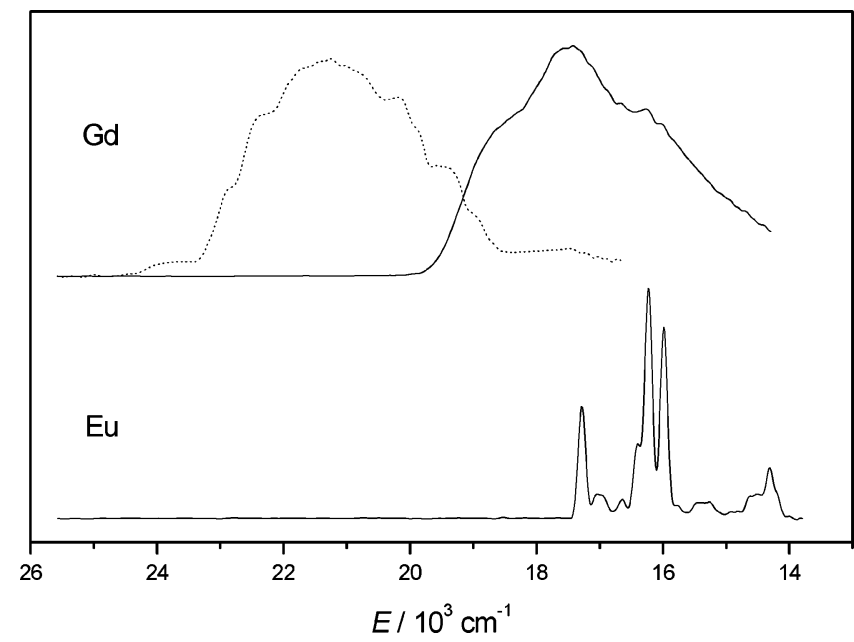

Figure 5. Corrected fluorescence spectrum of $\left[\mathrm{Gd}\left(\mathbf{L}^{2}-2 \mathrm{H}\right)\right]^{+}$in acetonitrile solution at $295 \mathrm{~K}$ (dotted line) and phosphorescence spectra (solid lines) of $\left[\operatorname{Ln}\left(\mathbf{L}^{2}-2 \mathrm{H}\right)\right]^{+}(\mathrm{Ln}=\mathrm{Gd}, \mathrm{Eu})$ in the solid state at $77 \mathrm{~K}$. Vertical scale: arbitrary units.

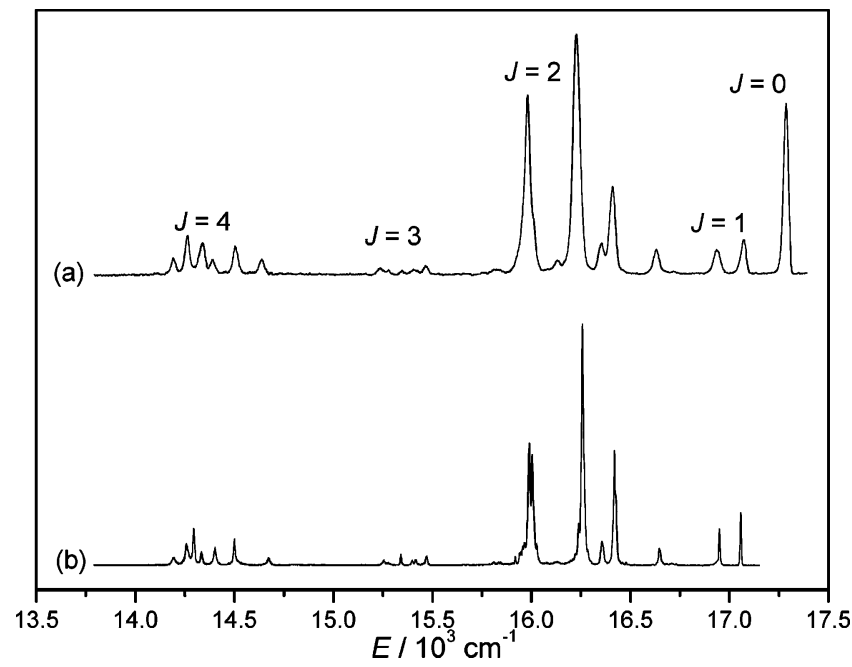

Figure 6. Corrected emission spectra of $\left[\mathrm{Eu}\left(\mathbf{L}^{2}-2 \mathrm{H}\right)\right]^{+}$(solid state, $10 \mathrm{~K}$ ) under various excitation conditions: $\tilde{v}_{\text {exc }}=$ (a) $23753 \mathrm{~cm}^{-1}$ and (b) 17 $285 \mathrm{~cm}^{-1}$. Vertical scale: arbitrary units.

$Q=0.32 \%$. The phosphorescence spectrum recorded in the solid state at $77 \mathrm{~K}$ presents a band with a maximum at ca. $17630 \mathrm{~cm}^{-1}$ and a zero-phonon component at $18750 \mathrm{~cm}^{-1}$ (Figure 5). This emission possesses a single-exponential time decay with a lifetime of $1.32 \pm 0.05 \mathrm{~ms}$ and is therefore assigned as arising from the ${ }^{3} \pi \pi^{*}$ state. The luminescence of the ligand ${ }^{1} \pi \pi^{*}$ and ${ }^{3} \pi \pi^{*}$ states disappears completely for the $\mathrm{Eu}(\mathrm{III})$ complex, indicating sensitization of the metal ion via a ${ }^{3} \pi \pi^{*}$-to-metal energy transfer (Figure 5).

A high-resolution study has been performed to gain information on the chemical environment of the $\mathrm{Eu}(\mathrm{III})$ ion. Upon excitation in the ligand ${ }^{1} \pi \pi^{*}$ state at $10 \mathrm{~K}$, the emission spectrum displays the characteristic $\mathrm{Eu}\left({ }^{5} \mathrm{D}_{0} \rightarrow{ }^{7} \mathrm{~F}_{J}\right)$ transitions (Figure 6a). The integrated and corrected relative intensities of the ${ }^{5} \mathrm{D}_{0} \rightarrow{ }^{7} \mathrm{~F}_{J}$ transitions are $1.9,1.00,9.9,0.6$, and 2.4 for $J=0,1,2,3$, and 4 , respectively. The ${ }^{5} \mathrm{D}_{0} \rightarrow{ }^{7} \mathrm{~F}_{0}$ transition, which is quite intense and reminiscent of a site with a $C_{n}$ (or $C_{n v}$ ) symmetry, occurs at $17292 \mathrm{~cm}^{-1}$. Excitation spectra of the nondegenerate ${ }^{5} \mathrm{D}_{0} \leftarrow{ }^{7} \mathrm{~F}_{0}$ transition measured at $10 \mathrm{~K}$ by monitoring the ${ }^{5} \mathrm{D}_{0} \rightarrow{ }^{7} \mathrm{~F}_{1}$ or ${ }^{5} \mathrm{D}_{0} \rightarrow{ }^{7} \mathrm{~F}_{2}$
Table 6. Energy of the ${ }^{7} \mathrm{~F}_{J}$ Sublevels $\left(J=1-4, \mathrm{~cm}^{-1}\right)$ of the Eu(III) Ion in Sites A and C, As Identified from Luminescence Spectra at $10 \mathrm{~K}$

\begin{tabular}{|c|c|c|c|c|c|}
\hline site & ${ }^{7} \mathrm{~F}_{0}$ & ${ }^{7} \mathrm{~F}_{1}$ & ${ }^{7} \mathrm{~F}_{2}$ & ${ }^{7} \mathrm{~F}_{3}$ & ${ }^{7} F_{4}$ \\
\hline \multirow[t]{7}{*}{ A } & 0 & 226 & 869 & 1823 & 2632 \\
\hline & & 332 & 936 & 1869 & 2808 \\
\hline & & 658 & 1040 & 1885 & 2893 \\
\hline & & & 1313 & 1954 & 2945 \\
\hline & & & & 2053 & 2994 \\
\hline & & & & & 3050 \\
\hline & & & & & 3094 \\
\hline \multirow[t]{7}{*}{ C } & 0 & 227 & 866 & 1814 & 2614 \\
\hline & & 334 & 928 & 1869 & 2785 \\
\hline & & 638 & 1029 & 1887 & 2884 \\
\hline & & & 1282 & 1946 & 2955 \\
\hline & & & 1297 & 2031 & 2991 \\
\hline & & & & & 3028 \\
\hline & & & & & 3094 \\
\hline
\end{tabular}

transitions display three main bands. The corresponding emission spectra recorded under selective excitation are similar but present some differences with respect to the ${ }^{5} \mathrm{D}_{0} \rightarrow{ }^{7} \mathrm{~F}_{2}$ transition, which confirms the presence of slightly distinct chemical environments labelled as A, B, and C (Figure S2, Supporting Information). The emission spectrum of site C (Figure 6b) may be interpreted in terms of a lowsymmetry around $\mathrm{Eu}(\mathrm{III})$, derived from a higher pseudotetragonal symmetry such as the one evidenced in the crystal structure determinations of $\mathbf{2}$ and $\mathbf{5 b}$. The transition to ${ }^{7} \mathrm{~F}_{1}$ displays three components, one of which has quite a high energy (638 $\mathrm{cm}^{-1}$; cf. Table 6). The two components appearing at low energy can be thought as arising from the splitting of the ${ }^{7} \mathrm{~F}_{1}\left(\mathrm{E}_{\mathrm{g}}\right)$ sublevel in tetragonal symmetry induced by the distortion of the coordination polyhedron evidenced in the crystal structures. The splitting of the ${ }^{7} \mathrm{~F}_{1}$ level in tetragonal symmetry is governed by the $\mathrm{B}_{0}{ }^{2}$ crystal field parameter. Since the barycenter of the split $\mathrm{E}_{\mathrm{g}} \mathrm{com}-$ ponent lies at lower energy $\left(280 \mathrm{~cm}^{-1}\right)$ than the $A_{2 g}$ component $\left(638 \mathrm{~cm}^{-1}\right)$, this parameter is positive and its value can be estimated to about $1600 \mathrm{~cm}^{-1}$ from a known linear correlation. ${ }^{40}$ The distortion from the idealized symmetry implies the disappearance of the $C_{4}$ axis, and in addition to $\mathrm{B}_{0}{ }^{2}$, another crystal field parameter determines the ${ }^{7} \mathrm{~F}_{1}$ splitting, $\mathrm{B}_{2}{ }^{2}$ which is proportional to $\Delta E_{\mathrm{EE}}$; the large value of the latter $\left(107 \mathrm{~cm}^{-1}\right)$ indicates a large distortion from the idealized square antiprism geometry. The other transitions are more difficult to interpret quantitatively, but the number of observed components is consistent with the above discussion. A careful analysis of the emission spectra of the other sites allowed us to assign most of the crystal field sublevels of the ${ }^{7} \mathrm{~F}_{J}$ manifold corresponding to site A (Table 6). The latter presents a distortion from the square antiprism geometry similar to the one evidenced for site $\mathrm{C}$ : $\Delta E_{\mathrm{EE}}=106 \mathrm{~cm}^{-1}$ while $\Delta E_{\mathrm{AE}}=379 \mathrm{~cm}^{-1}$ points to an even larger $\mathrm{B}_{0}^{2}$ parameter (on the order of $1700 \mathrm{~cm}^{-1}$ ).

The presence of at least three different $\mathrm{Eu}(\mathrm{III})$ coordination sites in the emission spectra of a solid-state sample of $\mathbf{6}$ may be due to several reasons. First, the presence of two stereoisomers may generate different spectra, as observed

(40) Görller-Walrand, C.; Binnemans, K. In Handbook on the Physics and Chemistry of Rare Earth; Gschneidner, K. A., Jr., Eyring, L., Eds.; Elsevier Science BV: Amsterdam, 1996; Vol. 23, Chapter 155. 
Table 7. Lifetimes of the $\operatorname{Eu}\left({ }^{5} \mathrm{D}_{0}\right)$ Level in $\left[\mathrm{Eu}\left(\mathbf{L}^{2}-2 \mathrm{H}\right)\right]^{+}$as Determined at $10 \mathrm{~K}$ under Different Experimental Conditions

\begin{tabular}{cccc}
\hline site & $\tilde{\boldsymbol{v}}_{\mathbf{e x c}} / \mathbf{c m}^{-\mathbf{1}}$ & $\tilde{\boldsymbol{v}}_{\mathrm{an}} / \mathbf{c m}^{-\mathbf{1}}$ & $\tau_{\mathrm{f}} / \mathrm{ms}$ \\
\hline A & 17285 & 16226 & $0.41(1)^{a}$ \\
& & 16241 & $0.40(1)^{a}$ \\
C & 17302 & 16265 & $0.38(1)^{a}$ \\
& & 16265 & $0.29(1)^{a}$ \\
I & 17285 & 17084 & $0.27(1)^{a}$ \\
II & 17305 & 15987 & $0.44(1)^{b}$ \\
III & 17328 & 15987 & $0.35(1)^{b}$ \\
& & 15987 & $0.63(1)^{b}$
\end{tabular}

${ }^{a}$ Solid state. ${ }^{b}$ Frozen acetonitrile solution.

in dipicolinate derivatives, ${ }^{41}$ and second, the crown moiety may take several slightly different conformations, as indicated by the disorders observed in the crystal structures of $\mathbf{2}$ and $\mathbf{5 b}$, which in turn result in differences in the crystal field effect. ${ }^{42}$ These different conformations of the crown moiety are not always resolved by X-ray determinations, which yield an average representation of the unit cell. However, the faster time scale of luminescence experiments provides an instantaneous representation of it.

At low temperature, the lifetimes of the $\mathrm{Eu}\left({ }^{5} \mathrm{D}_{0}\right)$ level are short (0.3-0.5 ms, Table 7) and the Eu(III) emission is nearly completely quenched at room temperature. This is indicative of a temperature-dependent quenching mechanism such as mixing with ligand vibrational modes, photoinduced electrontransfer processes, or back transfer to the ${ }^{3} \pi \pi^{*}$ state of the ligand. Reinhoudt and co-workers ${ }^{43}$ have concluded from their work on modified Eu(III)-containing calix[4]arenes that the antenna effect is improved when the ${ }^{3} \pi \pi^{*} 0$-phonon transition lies $3500 \mathrm{~cm}^{-1}$ above the lanthanide excited state. They also observed that the ${ }^{1} \pi \pi^{*} \rightarrow{ }^{3} \pi \pi^{*}$ intersystem crossing is maximized when the energy difference between these states amounts to ca. $5000 \mathrm{~cm}^{-1}$. A similar conclusion was reached by Latva et al., ${ }^{44}$ finding that the best efficiency in energy transfer is obtained when the 0 -phonon band of ${ }^{3} \pi \pi^{*}$ lies at $21000-22000 \mathrm{~cm}^{-1}$. In the Eu(III) complex 6, the 0 -phonon transition of the ligand ${ }^{3} \pi \pi^{*}$ state (as measured for the gadolinium complex in the solid state) lies at $18750 \mathrm{~cm}^{-1}$, leading to $\Delta E\left({ }^{3} \pi \pi^{*}-{ }^{5} \mathrm{D}_{0}\right)$ difference of ca. $1460 \mathrm{~cm}^{-1}$. Moreover, the ${ }^{1} \pi \pi^{*}-{ }^{3} \pi \pi^{*}$ energy difference for the Gd(III) complex amounts to only $3100 \mathrm{~cm}^{-1}$. These data explain the poor sensitization of the Eu(III) complex at room temperature, as well as the short lifetime of the ${ }^{5} \mathrm{D}_{0}$ level, a back transfer process onto the ligand being possible. However, the presence of a quenching by a ligand-to-metal charge transfer ${ }^{45}$ state cannot be ruled out either, but we were unable to locate a LMCT transition in the absorption spectrum of 6.

(41) Brayshaw, P. A.; Bünzli, J.-C. G.; Froidevaux, P.; Harrowfield, J. M.; Kim, Y.; Sobolev, A. N. Inorg. Chem. 1995, 34, 2068.

(42) Bünzli, J.-C. G.; Pradervand, G.-O. J. Chem. Phys. 1986, 85, 2489. Plancherel, D.; Jin, L.; Massara, R.; Bünzli, J.-C. G. Helv. Chim. Acta 1987, 70, 1807. Nicolo, F.; Plancharel, D.; Chapuis, G.; Bünzli, J.-C. G. Inorg. Chem. 1988, 27, 3518.

(43) Steemers, F. J.; Verboom, W.; Reinhoudt, D. N.; Vandertol, E. B.; Verhoeven, J. W. J. Am. Chem. Soc. 1995, 117, 9408

(44) Latva, M.; Takalo, H.; Mukkala, V. M.; Matachescu, C.; RodríguezUbis, J.-C.; Kankare, J. J. Lumin. 1997, 75, 149.

(45) Petoud, S.; Glanzmann, T.; Bünzli, J.-C. G.; Piguet, C.; Qin, X.; Thummel, R. P. J. Lumin. 1999, 82, 69.
We have also examined the luminescence properties of the $\mathrm{Nd}(\mathrm{III})$ complex 4. In $\mathrm{Nd}$ (III), the energy gap $\Delta E\left({ }^{4} \mathrm{~F}_{3 / 2} \rightarrow{ }^{4} \mathrm{I}_{15 / 2}\right)=5400 \mathrm{~cm}^{-1}$ is quite small and is easily matched by $\mathrm{C}-\mathrm{H}, \mathrm{O}-\mathrm{H}$, or $\mathrm{N}-\mathrm{H}$ vibrations. ${ }^{46}$ However, the luminescence spectrum of the $\mathrm{Nd}(\mathrm{III})$ complex 4 recorded in the solid state at $10 \mathrm{~K}$ under laser excitation of the ${ }^{4} \mathrm{G}_{9 / 2}$ level consists of a strong structured emission band assigned to the ${ }^{4} \mathrm{~F}_{3 / 2} \rightarrow{ }^{4} \mathrm{I}_{9 / 2}$ transition with components at 10800,11 020, 11 158, 11377 , and $11412 \mathrm{~cm}^{-1}$. Moreover, this strong emission is maintained at $295 \mathrm{~K}$, with a slight shift of the components to $10798,11005,11155,11285,11382,11$ 462 , and $11576 \mathrm{~cm}^{-1}$, indicating that the receptor $\left(\mathbf{L}^{2}-2 \mathrm{H}\right)^{2-}$ protects the $\mathrm{Nd}(\mathrm{III})$ ion from quenching or back transfer processes.

\section{Conclusions}

In its di-deprotonated form, the Schiff-base bibracchial lariat ether $N, N$ '-bis(2-salicylaldiminobenzyl)-1,10-diaza-15crown-5 is a strongly binding versatile ligand for coordination to the trivalent lanthanide ions. The $\mathrm{X}$-ray crystal structures of $\left[\mathrm{Ce}\left(\mathbf{L}^{2}-2 \mathrm{H}\right)\right]\left(\mathrm{ClO}_{4}\right) \cdot 0.5 \mathrm{H}_{2} \mathrm{O}(\mathbf{2})$ and $\left[\mathrm{Sm}\left(\mathbf{L}^{2}-2 \mathrm{H}\right)\right]\left(\mathrm{ClO}_{4}\right) \cdot$ $\mathrm{C}_{3} \mathrm{H}_{8} \mathrm{O}$ (5) show the metal ion being nine-coordinated and deeply buried into the cavity of the dianionic receptor. The complexes present a cryptand-like structure in the solid state due to the formation of a second pseudo-macrocycle through $\pi-\pi$ interaction between one of the phenol rings and one of the benzyl rings. ${ }^{1} \mathrm{H}$ and ${ }^{13} \mathrm{C}$ NMR studies on the $\mathrm{La}(\mathrm{III})$ complex point that the solid-state structure is essentially maintained in acetonitrile solution. High-resolution laserexcited emission spectra of the crystalline Eu(III) complex demonstrate the presence of several slightly different coordination sites arising from different conformations of the crown moiety and/or stereoisomers. The ligand-to-Eu(III) energy transfer is relatively efficient at low temperature, but back transfer is implied in the deactivation process, especially at room temperature, because the ligand triplet state lies at low energy; on the other hand, this low energy provides an efficient conversion of the visible light absorbed into nearinfrared light emitted by the $\mathrm{Nd}(\mathrm{III})$ ion.

Acknowledgment. M.G.-L., C.P.-I., F.A., A.d.B., and T.R.-B. thank the Ministerio de Ciencia y Tecnología and FEDER for financial support (Grant BQU2001-0796). C.F.G.C.G. thanks the Foundation for Science and Technology (FCT) of Portugal for financial support. J.-C.G.B. and D.I. thank the Swiss National Science Foundation and the Swiss Office for Science and Education (Contract C 00.0030) for financial support. This research was performed within the framework of the EU COST Action "Lanthanide Chemistry for Diagnosis and Therapy" (D18).

Supporting Information Available: X-ray crystallographic files, in CIF format, for $\mathbf{2}$ and $\mathbf{5 a}$, Table S1, listing selected angles for $\mathbf{2}$ and $\mathbf{5 a}$, Table $\mathrm{S} 2$, listing ${ }^{1} \mathrm{H}$ NMR data for compounds $\mathbf{3}, \mathbf{4}$, $\mathbf{6 , 8}, \mathbf{9}$, and 10, Figure S1, showing the COSY NMR spectrum of 5, and Figure S2, showing high-resolution excitation and emission spectra of $\left[\mathrm{Eu}\left(\mathbf{L}^{2}-2 \mathbf{H}\right)\right]^{+}$. This material is available free of charge via the Internet at http://pubs.acs.org.

\section{IC034024T}

(46) Yanagida, S.; Hasegawa, Y.; Murakoshi, K.; Wada, Y.; Nakashima, N.; Yamanaka, T. Coord. Chem. Rev. 1998, 171, 461. 